\title{
Information systems environmental alignment and business performance: A case study
}

\author{
A.K. Garg* \\ Principal Engineer (Economy and Finance), Department of Mines, \\ Private Bag 0049, Gaborone, Botswana \\ agarg@gov.bw \\ R.J.O. Joubert \\ Graduate School of Business Leadership, Midrand, \\ University of South Africa, Republic of South Africa \\ jouberjo@unisa.ac.za \\ R. Pellissier \\ Dean of Faculty, CIDA City Campus, 54 Commissioner Street, \\ Johannesburg, Republic of South Africa \\ rene.pellissier@tiscali.co.za
}

Received February 2005

\begin{abstract}
The studies to establish the relationship between the external environment and business performance have not produced any conclusive results. Moreover, the field combining environmental uncertainty, information systems (IS) strategy and business performance has not been well explored. Considering the gap in current research, this study conceptualises an information systems environmental alignment model. The model analysed the extent of support provided by IS strategy in the assessment of environmental uncertainty and also examined the impact of IS environmental alignment on business performance. Based on empirical data collected by means of a questionnaire from 22 commercial banks in South Africa (covering more than $90 \%$ of the commercial banking sector) and using the Partial Least Squares (PLS) technique, the study validated the IS environmental alignment model and found that banks were using IS support to assess the external environment of business. The results suggest that it is not the IS support or investment in information technology (IT) that impacts on business performance, but rather the effective use of IS support in meeting the information needs of the organisation. The study also found that profitability still remains the key measure of business performance in the banking sector in South Africa. These findings have major implications for IT investment by banks, and for the implementation of IS strategy and general investment in the banking sector. IS environmental alignment is becoming extremely important for business because of the substantial investment in IT and the uncertainty of the business environment.
\end{abstract}

*To whom all correspondence should be addressed.

\section{Introduction}

The potential of information systems (IS) in supporting organisational activities and helping them to gain competitive advantage has been widely recognised by researchers and the business community (Peters, Heng \& Vet, 2002), and advances in information technology (IT) over the last decade have made it possible to exploit the potential of IS/IT (Ward \& Peppard, 2002).

IT applications used to help organisations to gain competitive advantage, reduce competitive disadvantage, or meet other strategic enterprise objectives. Applications such as these are referred to as the strategic management of information technology and continue to be key issues in exploiting IT/IS capabilities to achieve higher business performance (Croteau \& Bergeron, 2001; Kearns \& Lederer, 2000; Zhang \& Lado, 2001). In this context, aligning business and IT strategies was an important issue for researchers during the 1990s (Henderson \& Venkatraman,
1990 \& 1993; Luftman, Papp \& Brier, 1999; Luftman, 2000). Most of the research was of a conceptual nature, however. Empirical studies of alignment by Chan, Huff, Barclay and Copeland (1997) and Luftman (2000) mostly examine US and Canadian firms. Kanungo, Sadavarti and Sriniwas (2001) examined public sector units in India. The theories in alignment models emphasise the effective use of IT/IS in meeting the needs of organisations, which is achieved by aligning organisational needs with IT/IS facilities. The focus, however, is to achieve competitive advantage in the marketplace by leveraging IT facilities and realising value from IT investment.

Factors such as globalisation, advances in IT/IS, global political turmoil, acts of terrorism, and war against terrorism have made the external environment of business more complex and affected the task environment. For example the attack of 11 September resulted in the collapse of many airlines as a result of a loss of confidence among customers, a phenomenon that affected business from the task 
environment. A country such as South Africa has an open economy (with imports and exports accounting for more than $50 \%$ of economic activities). The money and financial markets are volatile (with respect to the rand/dollar exchange rate), which indicates a turbulent and uncertain business environment in South Africa. These factors suggest that organisations will have to consider managing their external environments more seriously and rigorously than was the case in the last two decades. Accordingly, the role of IT/IS investment in organisations should address the current needs of organisations to realise returns from their investments.

Numerous studies have linked business performance with different aspects of the organisation, for example: strategic planning and business performance (Anderson, 2000); organisation communication capacity using IT and business performance (Anderson, 2001); and strategic success and business performance (Ansoff \& Sullivan, 1993). The studies to establish the relationship between the external environment and business performance have not produced any conclusive results, however. For example, Bergeron, Raymond and Rivard's (1999) study on environmental uncertainty and business performance failed to establish conclusive results. Moreover, the field combining environmental uncertainty, IS strategy and business performance has not been well explored. Salmela, Lederer and Reponen (2000) examined information system planning in a turbulent environment; Sambamurthy, Zmud and Byrd (1994) investigated the comprehensiveness of IT planning from a contingency approach, while Lederer and Mendelow (1990) studied the impact of the environment of the management of information systems. None of these three studies links its models to business performance.

Given the gaps in current research, the following broad objectives were considered in this study:

- To establish the relationship between business performance and business uncertainty due to the external environment of business

- $\quad$ To study the IS support provided by organisations for assessing environmental uncertainty

- $\quad$ To establish the impact of IS environmental alignment on business performance. The synergy between IS support and the organisation's requirement to asses environmental uncertainty is termed 'IS environmental alignment' in the study.

These objectives revolve around three management issues, namely: the management of environmental uncertainty, the role of IS in the organisation, and aligning IT investment with the needs of the organisation.

As a strategy to manage the external environment of business, this study deliberates on IS strategy support in assessing the uncertainty in the external business environment of an organisation. It should be noted that this study uses building blocks for strategy as presented by writers such as Badri, Davis and Davis (2000), Galbraith (1977), Grant (1991), Porter (1980) and Pfeffer and Salancik
(1978). Essentially, the theoretical scope of this study is the extension of the strategic management role of IS as a result of the enhanced capabilities of information systems in organisations to exploit the full potential of IS. The study uses the banking sector in South Africa as its sample, and the management of the external environment of the business represents the area of IS application.

\section{Information management and role of information in managing the environment}

The terms, IS and IT strategy, are used interchangeably in the literature. Information management (IM) has emerged as the most common brief name for the management of the use of IT in organisations (Frishammar, 2002). According to Earl (1989), the IM strategy is concerned with the role and structure of IT activities in the organisation, focusing on relationships between what we do with technology (IS strategy) and how we do it (IT strategy). Based on the research of Henderson and Venkatraman (1990 \& 1993), Chan, Huff, Barclay and Copeland (1998) identify three dimensions of IS strategy as: the type and capabilities of IS, the IS support provided for business strategy, and IS governance issues. Zhang and Lado (2001) identify IS as an effective and efficient tool for gathering and processing strategically important information from external sources. According to Davies (2002) an IS strategy consists of a specification of the information systems needed to support organisational activity in the area of collection, storage, dissemination and use of information and should include details of the current and future IS portfolio. This study uses a definition that is consistent with Broadbent (1996) to differentiate between IT and IS. IT includes computers and communication technology such as hardware, software, telecommunication and communication networks (Broadbent, 1996). Broadbent further explains that information systems are formal organisational systems that rely on IT and that organisations must have IS to facilitate the management and control of IT resources. This study proposes an overall framework for IM, as shown in Figure 1. According to this framework, the objectives of IM are the management of an organisation's demand for information, while IT/IS constitute the supply side of demand, and IT is at the core of any information systems. While this framework provides interlinks between IM, IT and IS, the focus in this study is on IS. Any reference to IS in this study refers to the model proposed in Figure 1 (that is, IS with IT at its core, unless otherwise stated). This further refers to investments made in IT (hardware, software and communication networks) that in turn impact the IS processing and predicting capabilities of an organisation. In other words, information systems are systems that essentially rely on IT, and investments in IT facilities would enhance IS capabilities. These IS capabilities can provide IS support for the needs of organisations.

Information is regarded as valuable, but the IS function is not regarded as equally valuable (Avison, Cuthbertson \& Powell, 1999). Organisations have made substantial investments in IT (hardware, software, communication networks), which have impacted the IS capabilities. To exploit the full potential of IS capabilities, this investment must be aligned with organisational needs, which could also 
provide competitive advantage. IS cannot run businesses per se, but it can provide support to businesses in meeting their needs and improving their performance. Accordingly, a conceptual framework is proposed for the effective use of IS in organisations (see Figure 2). This framework is an extension of the strategic information systems era in the framework of Ward and Peppard (2002). Figure 2 shows an information tower, at the centre of which is the information. This information core is an additional core to the framework suggested in Figure 1, which depicts IT surrounded by IS. This framework suggests that the potential of IS can be exploited organisation wide. Corporate strategy alignment in Figure 2 refers to the alignment of corporate functions (such as external environment scanning and the selection of a business portfolio) with the functions of IS. The purpose of such alignment is the effective use of the IS facilities of the organisation and/or achieving competitive advantage from the alignment. The framework of IS structural alignment, proposed by Brown and Magill (1994), which aligns IS functions with the enterprise, with special reference to IS structure in organisation, is an example in this category. The IS environmental alignment proposed in this study explores aligning the assessment of environmental uncertainty (a function of corporate strategy) with IS support. Business strategy alignment in Figure 2 refers to the alignment of business unit functions with the functions of IS for the effective use of IS facilities deployed by organisations and/or achieving competitive advantage from the alignment. The strategic alignment model proposed by Henderson and Venkatraman (1990), Chan et al. (1997) and Luftman (2000) are examples in this category. Operational strategy alignment in Figure 2 refers to the alignment of the operational functions of an organisation with the functions of IS for the effective use of IS facilities deployed by the organisation. Examples include office automation systems and transaction-processing systems.

According to Galbraith (1977: 36), uncertainty is the difference between the amount of information required to perform the task and the amount of information that the organisation already possesses. Moreover, the difference between these two amounts is the relative uncertainty that the organisation faces, and represents the amount of information that must be acquired and processed by decision makers. Figure 3 shows the determinants of information and task uncertainty. Research demonstrates that top executives who invest more in information-seeking activities related to environmental scanning generally enhance the firm's financial performance (Boyd \& Fulk, 1996). The correct assessment of the environment is related to organisational effectiveness, and organisations that perceive the objective environment incorrectly will be less effective (Galbraith, 1973). This lack of understanding of the environment can waste a firm's resources for years (Badri et al., 2000). The basic theme of the Pfeffer and Salancik's (1978) resource dependence theory is to understand organisational behaviour and how the organisation relates to other social actors in its environment. The essence of formulating competitive strategy is relating a company to its environment (Porter 1980). The business environment is dynamic, and the organisation needs to gauge that environment in order to manage the aspects of uncertainty. The role of information becomes critical in the management of the environment.

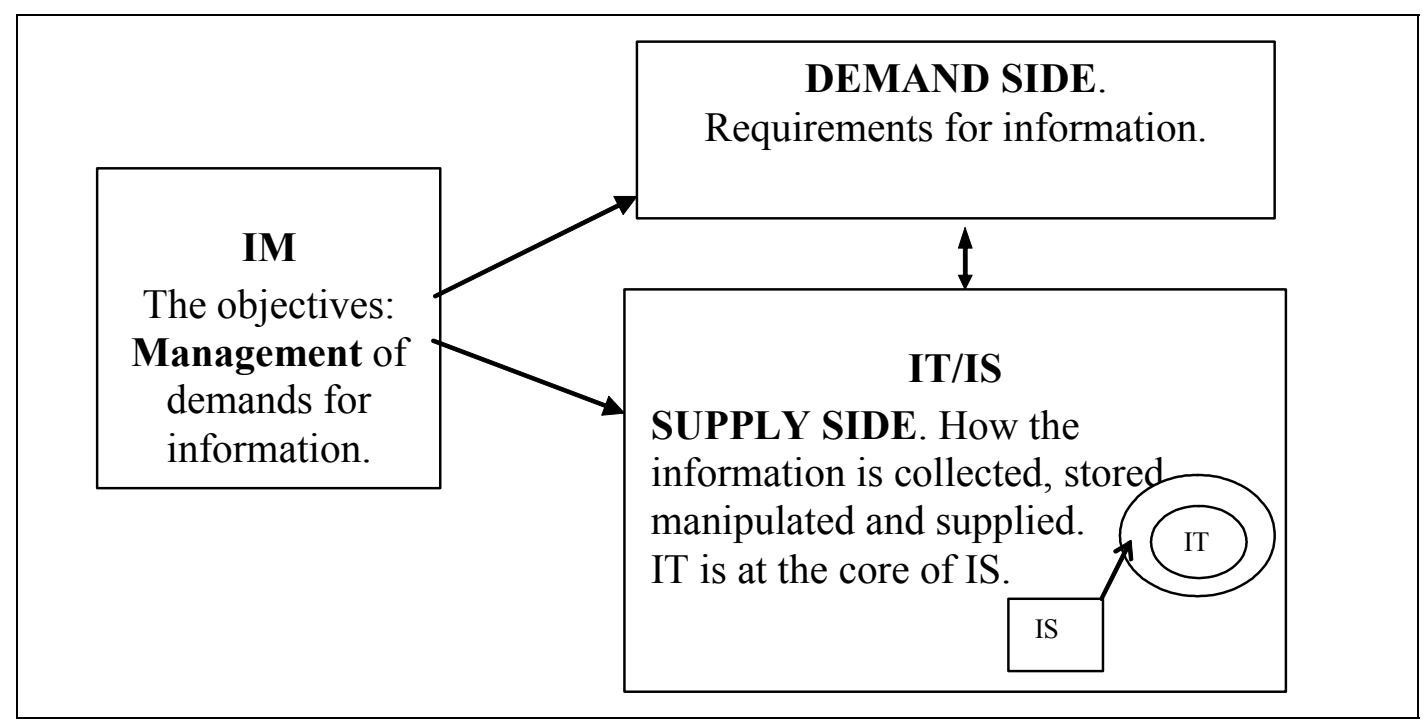

Source: Garg (2003)

Figure 1: Objectives in information management 


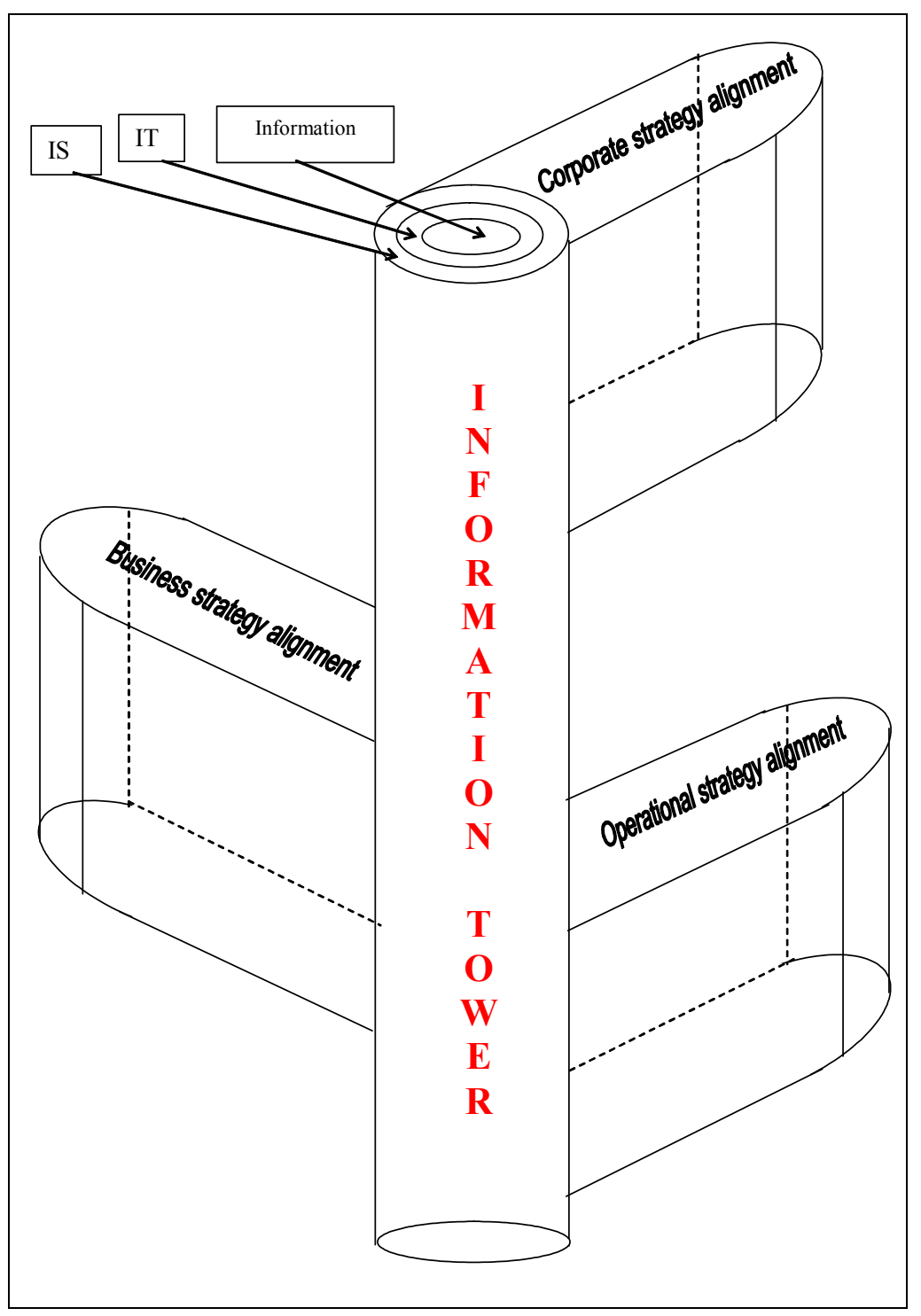

Figure 2: The tower of alignment for the effective use of IS in organisations (Garg 2003)

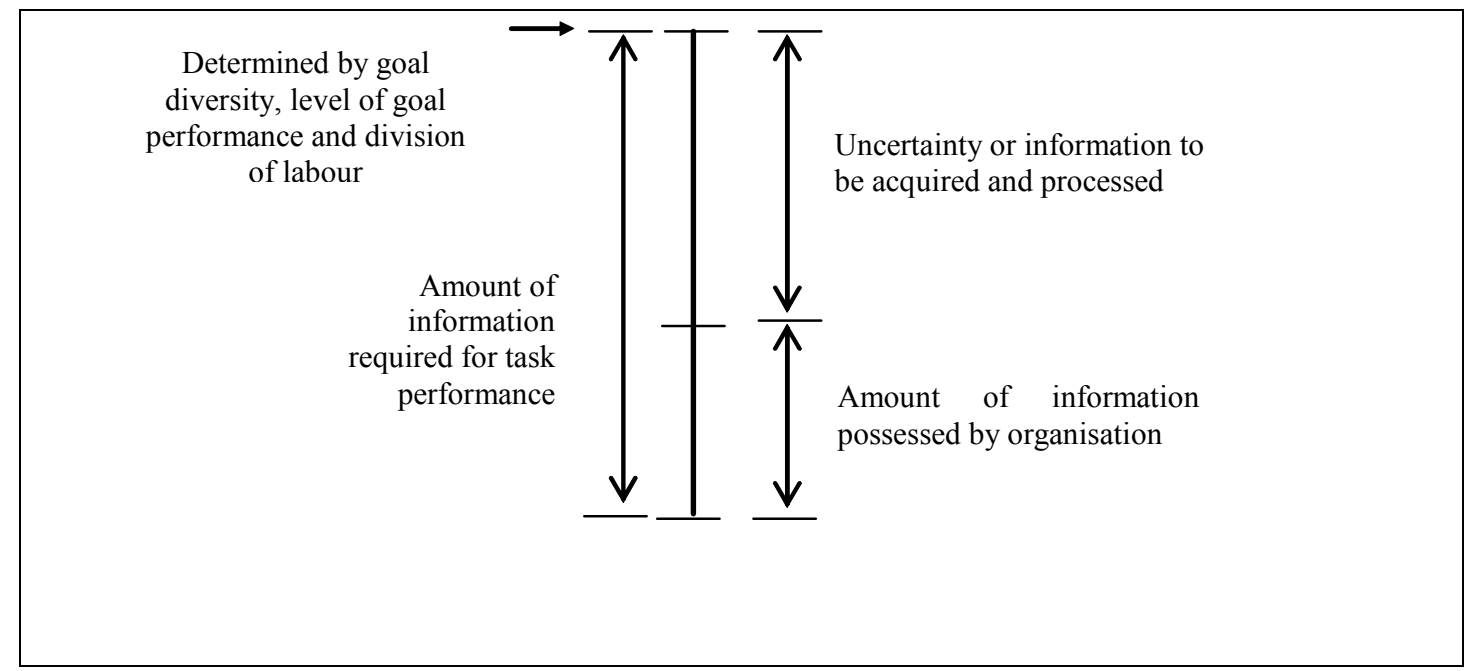

Source: Galbraith (1977)

Figure 3: Determinants of information and task uncertainty 


\section{Theoretical foundation of IS environmental alignment model}

The research on environmental uncertainty converges on three key issues (Garg, Joubert \& Pellissier, 2003):

a. The task environment is the primary force to which organisations must respond (Sawyerr, 1993; Ebrahimini, 2000).

b. It is the unpredictability of change that is associated with environmental uncertainty (Milliken, 1987).

c. The measurement of environmental uncertainty is a subjective phenomenon (Duncan, 1972; Miles \& Snow, 1978; Milliken, 1987; Sawyerr, 1993; Ansoff \& Sullivan, 1993; Ebrahimini, 2000).

Uncertainty arises as a result of imperfect and incomplete knowledge of the objective environment (Duncan, 1972; Milliken, 1987). Uncertainty in this context simply means the absence of information (Galbraith, 1977:36).

Organisations have made substantial investments in IT (hardware, software and communication) to enhance the information processing and predicting capabilities of their IS. (The investment in IT is at the core of IS; in other words, IS essentially relies on IT - see Figure 1). Zhang and Lado (2001) explain that IS may serve as an effective and efficient tool for gathering and processing information of strategic importance from external sources (such as customers, suppliers and dealers). They further explain that with online access to various external databases, executive information systems enable managers to search and to retrieve more external information about topics such as their suppliers, customers, competitors, financial organisations, stakeholders, regulatory bodies and interest groups in a timely manner.

As a basic rule, organisation's information processing capacity should be at least equal to or greater than the information processing needs (in other words, the supply of information should exceed the demand for information). IS strategy could thus play a significant role in minimising the gap between perceived environmental uncertainty and the objective/realised environmental conditions, by providing support to strategists in assessing environmental conditions. Figure 4 shows the perceived and realised conditions and the gap. It shows that perceived uncertainty is the area where there is no information, referred to as AB. Theoretically, an organisation can realise all of $\mathrm{AB}$, part of $\mathrm{AB}$ and hypothetically even more than $\mathrm{AB}$, if it possesses information processing and predicting capabilities that are able to predict with $100 \%$ accuracy. Practically, however, it is impossible to realise the whole of AB. For the purposes of elaboration, however, a simple case is shown in Figure 4. This shows that an organisation may realise $\mathrm{BC}$, which is equal to the additional information collected and processed as a result of enhancements made in IS capabilities. The gap AC thus created cannot be reduced to zero but can be minimised.
The perceived uncertainty is measured in terms of unpredictability of change, or is simply called unpredictability. It is logical that unpredictability of an environmental factor would be related to the gap in perceived and realised environmental conditions. This would mean that higher unpredictability of an environmental factor would result in bigger gaps than in the case of an easily predictable factor, or that unpredictability is directly proportional to the gap. This is illustrated in Figure 5.

According to Smircich and Stubbart (1985:726) strategists must minimise the gap between their flawed perceptions and the objective environment and use the analysis to identify perceived opportunities and threats (Langford \& Hunsicker, 1996).

Two aspects are pertinent in this regard: (i) to minimise the gap between perceived and objective environment/realised environment conditions, and (ii) to identify opportunities and threats and act upon them.

The issue of identifying opportunities and threats and acting accordingly is the area of business strategy. In this context, Henderson and Venkatraman (1990) refer to aligning business strategy and IT strategy to leverage IT for competitive advantage as 'strategic alignment for strategic management of IT'.

To realise maximum benefits from IS strategy, it is essential to align IS strategy (its support dimension) with the assessment of perceived environment uncertainty. This alignment is referred to in this study as IS environmental alignment. The strategic alignment (Henderson \& Venkatraman, 1990) and structural alignment (Chan, 1997) are basically business unit level issues, while IS environmental alignment is primarily a corporate level issue and represents corporate strategy alignment in terms of the tower of alignment (see Figure 2). The IS environmental alignment becomes extremely important for business because of the substantial investment in IT and the uncertainty of the business environment.

However, studies dealing with the impact of environmental uncertainty and moderating the effect of uncertainty on business performance are not well established. For example:

- Lumpkin and Dess (2001) studied the moderating role of the environment and industry lifecycle and found that environmental dynamism moderates the relationship between proactiveness and firm performance. Their results do not support the moderating role of environmental hostility between proactiveness and firm performance.

- Matching flexibility to the level of environmental uncertainty does not lead to a performance advantage (Pagell \& Krause, 1999). The findings of Pagell and Krause suggest that many companies respond to changes in their competitive environment by focusing on priorities other than flexibility. 


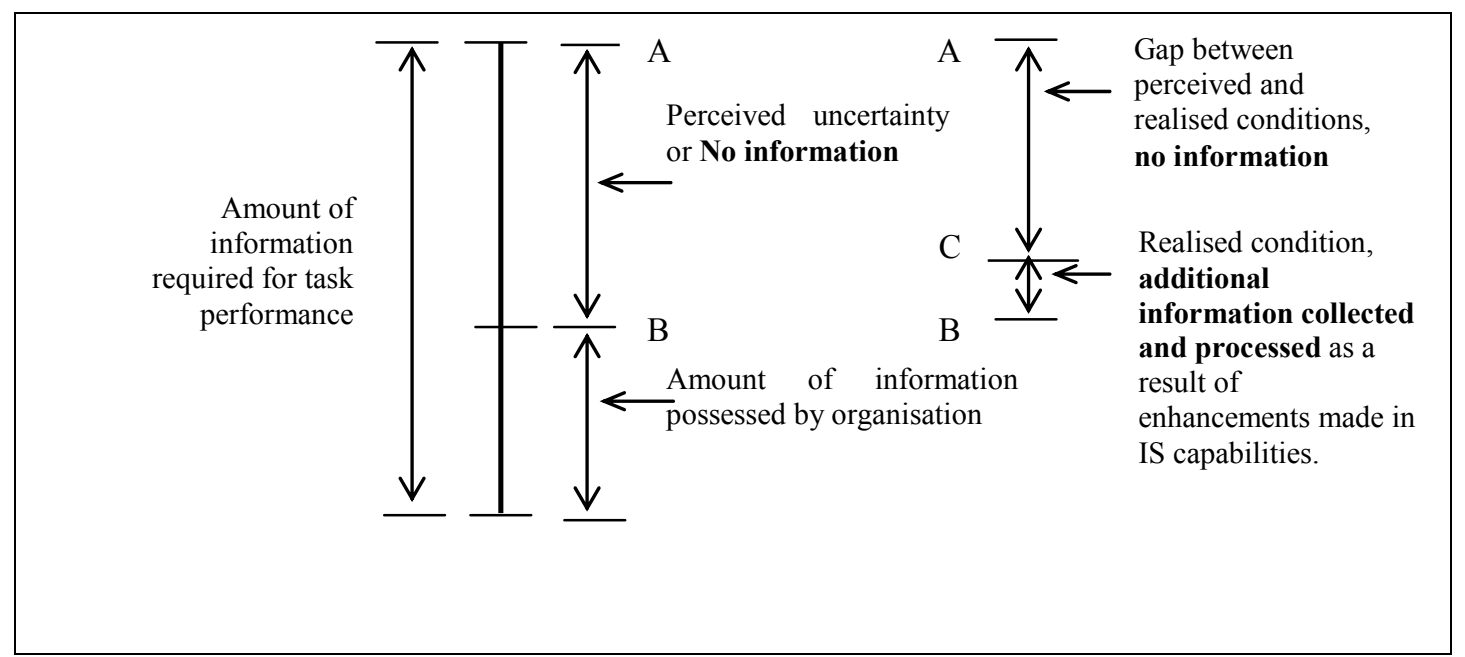

Source: Adapted from Galbraith (1977)

Figure 4: Gap between perceived and realised conditions

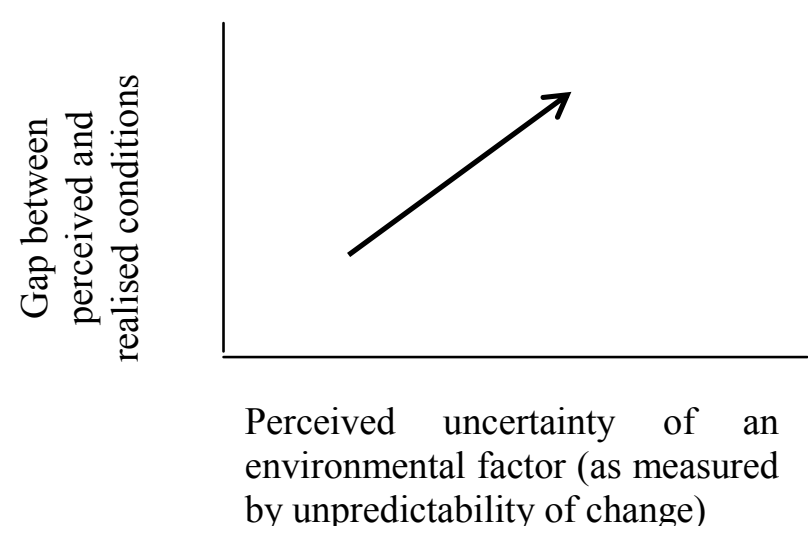

Figure 5: Relationship between perceived uncertainty and gap between perceived and realised conditions

- $\quad$ Bergeron et al. (1999) report that the environmentaltechnology fit does not appear to predict or explain business performance, whatever approach is taken.

- Successful organisations (high performers) adopt competitive priorities that best fit the conditions of the environment, notably stability and dynamism. Most firms accept their environment as given and install mechanism to react to its forces. High performers match the complexity of their external environment by utilising environmental variables as sources of effective controls within their organisations (Badri et al., 2000).

The foregoing discussion indicates how IS complements business with specific reference to the relationship between the external environment of business, IT/IS application and business performance. On the basis of previous research, the present study proposes that the alignment of business functions with IS support is necessary all over the organisations, and not in a scattered manner, as proposed by various researchers (Henderson \& Venkatraman, 1990; Chan et al., 1997). Figure 2 (tower of alignment) captures this concept, as discussed earlier. In this respect, strategic alignment emerges as a critical issue, and a brief literature review is reported in the next section.

\section{Brief literature review on strategic alignment}

'Strategic alignment' (Henderson \& Venkatraman, 1993; Luftman \& Oldach, 1996; Chan \& Huff, 1993a; Papp, 1995), 'linkage' (Reich \& Benbasat, 1996) and 'harmony' (Woolfe, 1993) are the various terms that describe the concept of business and IT strategy alignment. The alignment models developed during the last decade focused on various dimensions and domains of alignment. For example, the Strategic Alignment Model developed by Henderson and Venkatraman (1990 \& 1993) focuses on four domains: business strategy, IT strategy, organisational infrastructure and processes, and IT infrastructure and processes. Chan and Huff (1993a \& 1993b) focus on business and IS strategic orientation. Pankratz (1991) 
highlights four main areas: business strategy, IT strategy, organisational strategy and culture, and finance strategy. Kanungo et al. (2001), analyse the relationship between selected aspects of organisational culture and IT strategy in public sector units. Sun and Hong (2002) identify the contribution of manufacturing performance to business performance. Brown and Magill (1994) examine the alignment of the IS function with the enterprise. Researchers, for example Chan et al. (1997), Henderson and Venkatraman (1993) and Luftman (2000), have studied the intellectual dimension of strategic alignment extensively, while Reich and Benbasat (1996) studied its social dimension. Tan (1999) attempted to explore the nature of the social dimension of alignment and its relationship with the intellectual dimension.

Important studies on alignment (Garg, Joubert \& Pellissier, 2002) are summarised in Table 1.

Researchers have consistently argued (Henderson \& Venkatraman, 1993) that failure to obtain returns from IT investment is partly due to lack of alignment between the IT strategy and business needs (that is, the business strategy), but empirical evidence is available only for some Western countries. Empirical studies of alignment by Chan and Huff (1997) and Luftman (2000) mostly examine US and Canadian firms. Kanungo et al. (2001) examine public sector units in India.

The Strategic Alignment Model provides a theoretical framework for aligning business and IT strategy. The South African business landscape is not necessarily comparable and analogous to that in the countries tested by the conceptual model of Henderson and Venkatraman (1993) and other researchers. Chan et al. (1997) were unable to show any positive effects of IS strategic alignment on the financial performance of a firm. Other studies indicate the importance of the subject for both organisations and researchers. However, none of the models discussed consider the environmental uncertainty that could impact business performance. The impact of IT/IS on organisational financial performance is an important concept for further study. These conclusions form the background to the study of strategic alignment in the South African context.

\section{Models of alignment and information systems environmental alignment model}

Researchers have conceptualised various models of alignment, and have essentially considered aligning business strategy and IT strategy to gain competitive advantage in the marketplace (for example, the Strategic Alignment Model of Henderson and Venkatraman [1990]). These models were conceptual, and the advancements in the structural equation modelling (SEM) techniques using second generation data analysis techniques (namely, LISREL and PLS) have allowed researchers to validate these models using empirical data - for example, Chan et al. (1997), Papke-Shields and Malhotra (2001), Sun and Hong (2002). The various basic alignment models are summarised in Table 2.
All the models of alignment (referred to in Table 2) consider the effective use of IT/IS in business, or the extent to which IT/IS complements business. The theory in the models can be explained by using the example of a fresh fruit or meat hawker, who would almost certainly make more profits if he or she were to invest in and use a calculator and an electronic weighing machine. This is because of the nature of the product he/she is selling. He/she would do even better by further investing in an electronic organiser and feeding in data such as daily sales and using this information to estimate sales for the next day and the collection of debt. Similarly, in any other business, business performance would improve if IT/IS investments were made and effectively used or aligned with organisational needs in the framework of tower of alignment (Figure 2). Based on moderation fit, in a model of alignment, business performance would be predicted better by the effective use of IT/IS, compared with directly related factors of alignment.

Organisations need to manage the external environment of business and devise strategies to deal with it. Improving information processing and predicting capabilities as a strategy for managing the external environment is effective only when the investments made in IT/IS are aligned with the requirements of the organisation. However, to realise maximum benefits from IS strategy, it is essential to align IS strategy (its support dimension) with the assessment of perceived environment uncertainty, which is referred to as 'IS environmental alignment'. IS environmental alignment becomes extremely important for business because of the substantial investment in IT/IS and the uncertainty of the business environment.

As discussed earlier, the 'unpredictability' of an environmental factor refers to 'the unpredictability of change' of the factor and is the measure of uncertainty associated with the factor. It is logical that the unpredictability of an environmental factor would be related to the gap in the perceived and realised environmental condition. This would mean that higher unpredictability of an environmental factor would result in bigger gaps than in the case of an easily predictable factor or, in other words, unpredictability is proportional to the gap (Figure 5). This gap cannot be reduced to zero in practical situations, but IS support in assessing the uncertainty would help in reducing the gap (Figure 4 ). Higher IS support would be required for a higher gap situation in perceived and realised conditions. The implications are explained in Table 3.

Referring to Figure 5 the following equality is derived:

Perceived uncertainty (PNV) $\alpha$ Gap

[ $\alpha$ refers to directly proportional]

$=>\mathrm{PNV}=$ Constant $\mathrm{X}$ Gap

$=>\mathrm{PNV} \approx$ Gap, assuming the value of constant $=1$ 
Table1: Studies on alignment

\begin{tabular}{|c|c|c|}
\hline Author(s) & Topic & Focus \\
\hline Brown \& Magill (1994) & $\begin{array}{l}\text { Alignment of the IS functions with the } \\
\text { enterprise }\end{array}$ & $\begin{array}{l}\text { The concepts and patterns of centralised, } \\
\text { decentralised and hybrid design structures of IS } \\
\text { and the reason for choosing an IS system }\end{array}$ \\
\hline Chan 1997 & $\begin{array}{l}\text { Business unit structure and structure of IS } \\
\text { functions }\end{array}$ & $\begin{array}{l}\text { The appropriateness/ inappropriateness of the IS } \\
\text { function's position within the enterprise, IS } \\
\text { reporting relationships, and centralisation/ } \\
\text { decentralisation of IS services and infrastructure }\end{array}$ \\
\hline Croteau \& Bergeron (2001) & $\begin{array}{l}\text { Business strategy, IT strategy (in the } \\
\text { framework of technological deployment) and } \\
\text { business performance }\end{array}$ & $\begin{array}{l}\text { Various profiles of technology deployment } \\
\text { specific to various types of business strategy } \\
\text { that best support organisational performance }\end{array}$ \\
\hline Cragg, King \& Hussain (2002) & Business and IT strategy & $\begin{array}{l}\text { Focused on small manufacturing firm and } \\
\text { investigated the link between alignment and } \\
\text { performance }\end{array}$ \\
\hline $\begin{array}{l}\text { Henderson \& Venkatraman 1990; Chan } \\
\text { et al. } 1997\end{array}$ & $\begin{array}{l}\text { Business strategy, IT/IS strategy, business } \\
\text { infrastructure and IT infrastructure }\end{array}$ & $\begin{array}{l}\text { Priorities and activities of business strategy, } \\
\text { priorities and activities of IT/IS strategy and } \\
\text { business performance }\end{array}$ \\
\hline Kanungo, Sadavarti \& Srinivas (2001) & IT strategy and organisational culture & $\begin{array}{l}\text { Organisational cultures were assessed in terms } \\
\text { of innovative, supportive and bureaucratic } \\
\text { cultures, while IT strategies were viewed as } \\
\text { comprising six generic strategies }\end{array}$ \\
\hline Papke-Shields \& Malhotra (2001) & $\begin{array}{l}\text { Organisational, manufacturing strategies and } \\
\text { business performance }\end{array}$ & $\begin{array}{l}\text { Involvement of manufacturing executives in } \\
\text { strategic decision-making process }\end{array}$ \\
\hline Reich \& Benbasat (1996) & $\begin{array}{l}\text { Short-term and long-term aspects of social } \\
\text { dimension of linkage }\end{array}$ & $\begin{array}{l}\text { The levels of understanding of business and IT } \\
\text { mission, objectives, and plans by IS and } \\
\text { business executives }\end{array}$ \\
\hline Sun \& Hong (2002) & $\begin{array}{l}\text { Business strategy, manufacturing strategy, } \\
\text { manufacturing performance and business } \\
\text { performance }\end{array}$ & $\begin{array}{l}\text { Contribution of manufacturing performance to } \\
\text { business performance }\end{array}$ \\
\hline
\end{tabular}

Table 2: Models of alignment

\begin{tabular}{l|l|l}
\hline \multicolumn{1}{c|}{ Models of alignment } & \multicolumn{1}{c}{ Elements of alignment } & Focus \\
\hline $\begin{array}{l}\text { Strategic alignment model (Henderson } \\
\text { \& Venkatraman 1990); IS strategic } \\
\text { alignment model (Chan et al. 1997) }\end{array}$ & $\begin{array}{l}\text { Business strategy, IT/IS strategy, business } \\
\text { infrastructure and IT infrastructure }\end{array}$ & $\begin{array}{l}\text { Priorities and activities of business strategy, } \\
\text { priorities and activities of IT/IS strategy and } \\
\text { business performance }\end{array}$ \\
\hline $\begin{array}{l}\text { IS structural alignment (Chan 1997) } \\
\text { IS environmental alignment (this } \\
\text { study) }\end{array}$ & $\begin{array}{l}\text { Business unit structure and structure of IS } \\
\text { functions } \\
\text { environment) and IS strategy }\end{array}$ & $\begin{array}{l}\text { The appropriateness/ inappropriateness of the IS } \\
\text { function's position within the enterprise, IS } \\
\text { reporting relationships, and centralisation/ } \\
\text { decentralisation of IS services and infrastructure }\end{array}$ \\
\hline
\end{tabular}


Table 3:Effectiveness of IT use (IS capability) and its implication on IS environmental alignment

\begin{tabular}{|c|c|c|c|c|}
\hline $\begin{array}{c}\text { Perceived uncertainty of } \\
\text { an environmental factor } \\
\text { (as measured by } \\
\text { unpredictability of } \\
\text { change) }\end{array}$ & $\begin{array}{c}\text { Gap between perceived } \\
\text { uncertainty and realised } \\
\text { environmental conditions } \alpha \\
\text { or } \approx \text { Environmental factor } \\
\text { uncertainty }\end{array}$ & $\begin{array}{l}\text { IS support provided } \\
\text { in reducing the gap } \approx \\
\text { IS support in } \\
\text { perceiving/ assessing } \\
\text { the factor } \\
\text { uncertainty } \\
\end{array}$ & $\begin{array}{l}\text { Effectiveness of IT use } \\
\text { or IS capabilities }\end{array}$ & $\begin{array}{c}\text { IS environmental } \\
\text { alignment }\end{array}$ \\
\hline High* & $\begin{array}{l}\text { High } \\
\text { High }\end{array}$ & $\begin{array}{l}\text { High } \\
\text { Low }\end{array}$ & $\begin{array}{l}\text { Effective } \\
\text { Ineffective }\end{array}$ & $\begin{array}{l}\text { Good } \\
\text { Poor }\end{array}$ \\
\hline Low** & LowLow & HighLow & WasteEffective & $\begin{array}{l}\mathrm{Bad} / \text { superimposed } \\
\text { Good }\end{array}$ \\
\hline
\end{tabular}

*Say 4 on rating scale of $1-6,{ }^{* *}$ Say 2 on rating scale of $1-6$

Based on the preceding logic, the IS environmental alignment model is conceptualised in Figure 6. In the model, perceived uncertainty of the task environment refers to the uncertainty as perceived by the individual in the task environment (including competitors, suppliers and customers). IS strategy orientation towards perceived uncertainty is the support provided by the information systems that rely on IT and are used by the organisation to reduce the gap between perceived environmental and realised environmental conditions (In other words, IS support in perceiving/assessing environmental factor uncertainty). IS environmental alignment is the degree of fit between the perceived uncertainty of the task environment and the IS strategy orientation towards perceived uncertainty. The alignment measures the effective use of IS by the organisation.

The model uses the alignment measurement based on moderation fit proposed by Chan et al. (1997), as it provides a quantitative measure of alignment. The model is mathematically shown in Figure 7 , where $\xi_{1}$ is the perceived uncertainty of the task environment; $\xi_{2}$ represents IS strategy orientation towards perceived uncertainty; $\eta$ represents business performance; and $b_{1}, b_{2}, b_{3}$ are the correlation coefficients.

The examination condition can be represented mathematically as follows:

$\eta=b_{1} * \xi_{1}+b_{2} * \xi_{2}+b_{3} * \xi_{1} * \xi_{2}+\zeta$ and, according to alignment theory, $b_{3}$ should be greater than $b_{1}$, and $b_{3}$ should be greater than $b_{2}$. Also, $b_{3}$ should be greater than zero. $\xi_{1} * \xi_{2}$ represents the moderation type of alignment fit (Chan et al., 1997). This is the basic equation for the model.

\section{Hypothesis and objectives of the study}

The preceding model considers four variables, namely: i) perceived uncertainty of task environment; ii) business performance; iii) IS strategy orientation; and iv) IS environmental alignment.

Considering business performance as the dependent variable, environment uncertainty and IS strategy as independent variables, and IS environmental alignment as the moderator variable, the model posed the hypothesised that the IS environmental alignment has a positive effect on business performance $\left(\mathrm{H}_{1}\right)$, and this effect is more pronounced than the effect of perceived uncertainty of the task environment on business performance $\left(\mathrm{H}_{11}\right)$ and the effect of IS support on business performance $\left(\mathrm{H}_{12}\right)$. In other words, the value of $\mathrm{H}_{1}$ is greater than zero, and its value is higher than the values of $\mathrm{H}_{11}$ and $\mathrm{H}_{12}$.

The sub hypotheses were:

- Business performance is positively related to the perceived uncertainty of the task environment. This hypothesis is referred as $\mathrm{H}_{11}$ in the model, and mathematically $\mathrm{H}_{11}>0$. Researchers have established no direct relationship with respect to this aspect. However, Ansoff and Sullivan (1993) studied the effects on the profitability of the firm of aligning its strategic behaviour with its environment. Dess and Keats (1987) studied the effects of the accuracy of environmental assessment and organisational performance. Bergeron et al. (1999) were unable to establish a relationship between environmental uncertainty and performance.

- The IS strategy orientation towards perceived uncertainty is positively related to business performance. This is referred to as $\mathrm{H}_{12}$ in the model, and mathematically $\mathrm{H}_{12}>0$. In other words, higher investment in IT would result in higher business performance. As discussed earlier, IS strategy orientation is the support provided by IS that relies essentially on IT. The rationale in this regard is to study the direct effect of IT investment or the direct impacts of IS support on organisational performance. Past researchers, such as Henderson and Venkatraman (1990) and Chan et al. (1997) have dwelt on this aspect but have not empirically tested the relationship.

The objectives were to determine $\mathrm{H}_{1}, \mathrm{H}_{11}$ and $\mathrm{H}_{12}$, which required:

- Independently measuring the variables' perceived environmental uncertainty (PNV), IS strategy orientation (ISS) and business performance (BP).

- Calculating IS environmental alignment (ISA) from the measurements of PNV and ISS.

- $\quad$ Predicting BP from PNV, ISS and ISA (predictor variable) to establish the effect of each on BP. 


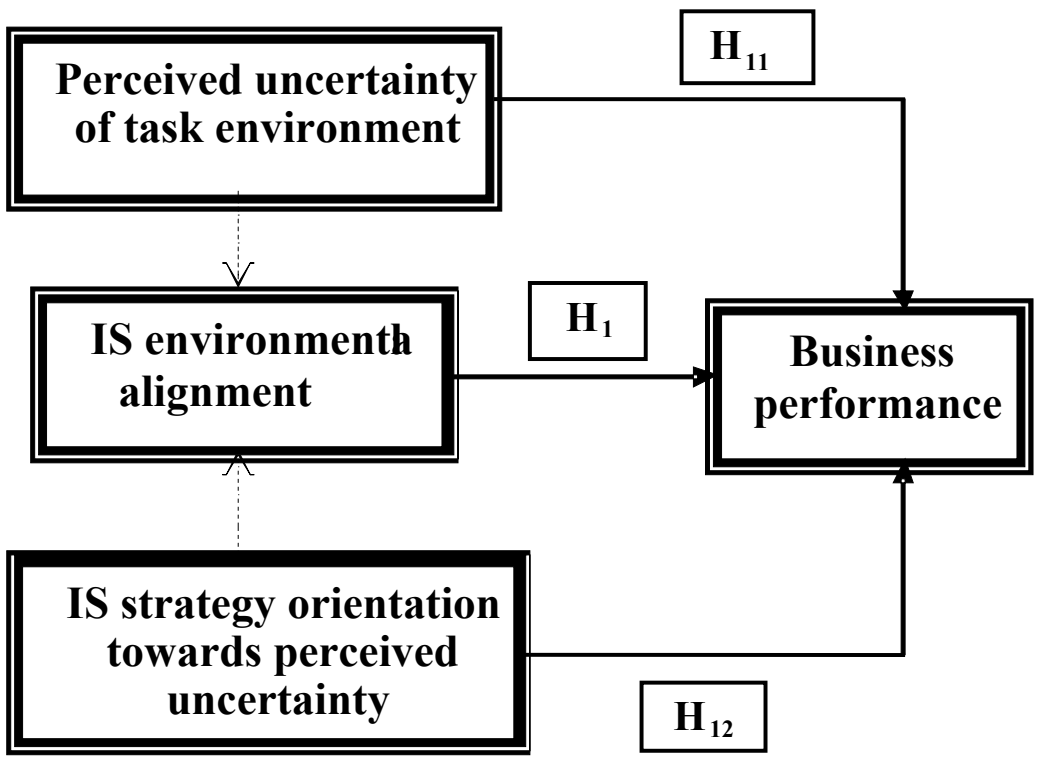

Note: Alignment measurement after Chan et al. (1997)

Figure 6: IS environmental alignment model

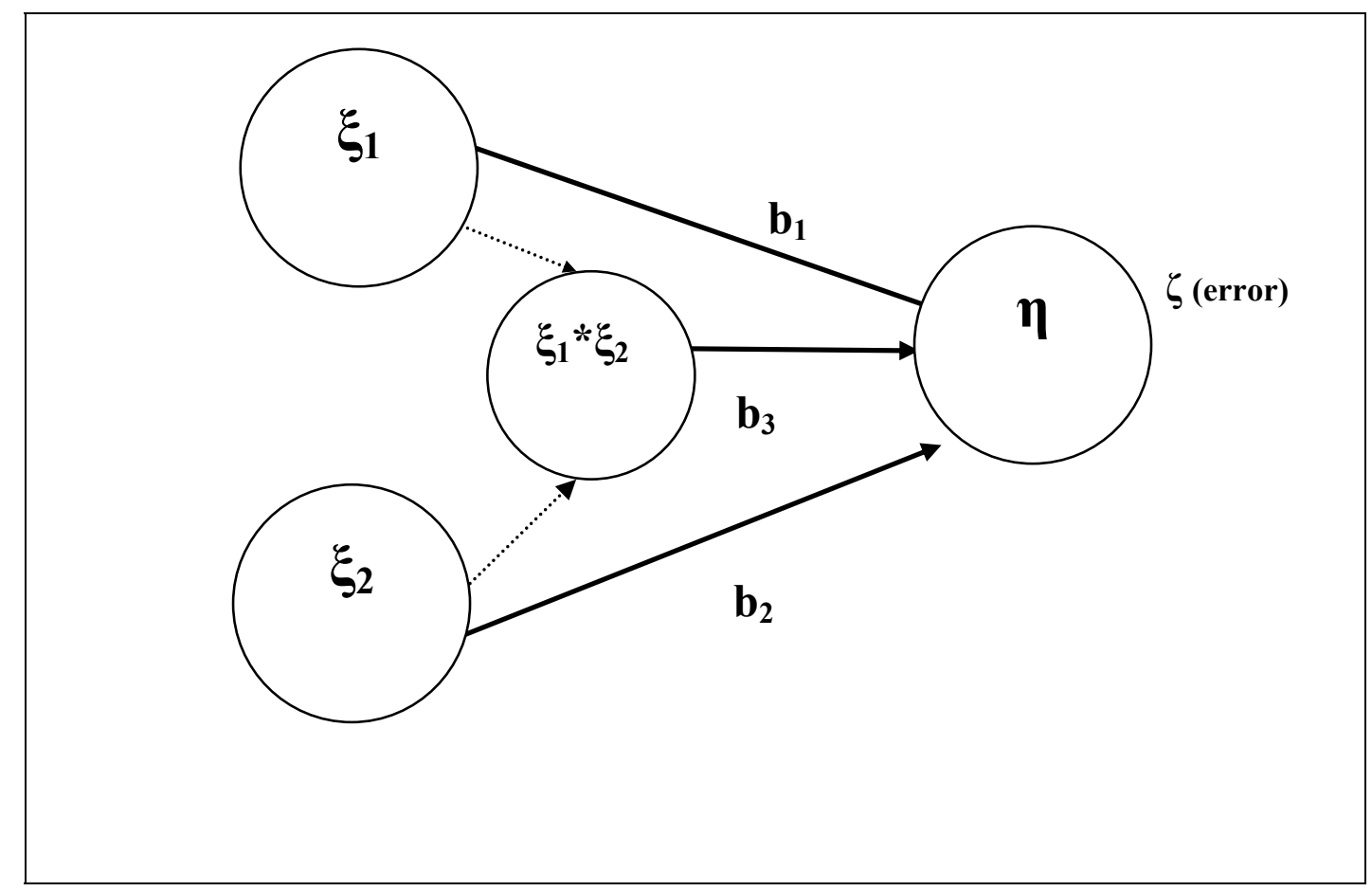

Figure 7: Mathematical representation of the conceptual model 


\section{Model validation}

\section{Sample selection}

The South African IT market has grown substantially over the last five years; with real growth rates of about $10 \%$ p.a. Growth rates in computer hardware sales (about 13\%) and in IT service markets (about 20\%) are almost double the global growth for the period 1999-2001 (South Africa Business Guidebook, 2001/2002).

South Africa has strong components of both the first world and developing world, and its banking sector has some of the most sophisticated information technology infrastructure worldwide, while the majority of small, medium and microenterprise have little or no access to IT systems (Groenewald, 1999).

Banking and finance sectors are investing over R1 billion in IT products and services, driven by the major banks, and the demand for information access tools is also expected to boost IT expenditure in the financial sector (South Africa Business Guidebook, 2001/2002). Forecasting a compound annual growth rate of $12 \%$ per annum, BMITechKnowledge (ITWeb, 2002) predicts that the total IT in banking spend in South Africa will grow from R4.5 billion in 2000 to over R10 billion in 2007. Moreover, biggest opportunity in this sector will remain in back-office integration, as the South Africa banking sector continues to streamline internal processes, as well as in business intelligence to help banks understand more about their customers. However, BMI-T (ITWeb, 2002) expects that banks will become more astute in their IT spending and evaluate expenditure more closely by spending on simplification and cost reduction processes.

Essentially, the following factors justify the selection of the sample: the South African banking sector's huge investment in IT, the need to study the extended role of IS facilities in organisations in the changing external environment of business and, last but not the least, the drive by organisations to realise returns on IT investments.

\section{Sample size determination}

The sample size in Partial Least Square (PLS) is the larger of the following two possibilities (Chin, 1998: 311):

a. The block with the largest number of formative indicators (in other words, the largest measurement equation) or

b. The dependent latent variable (LV) with the largest number of independent LVs influencing it.

If one were to use a regression heuristic of 10 cases per predictor, the sample size requirement would be 10 times either of (1) or (2) (Chin, 1998: 311). The sample size also has a direct and sizable impact on power (Hair, Anderson, Tatham \& Black, 1998:165). Power in multiple regression refers to the probability of detecting a specific level of $\mathrm{R}^{2}$ (or a regression coefficient) as statistically significant at a specified significance level for a specific sample size. In addition to the statistical power, sample size also affects the generalisability of the results by the ratio of observation to independent variables. A general rule is that the ratio should never fall below 5:1, meaning that there should be five observations for each independent variable in the variate (Hair et al., 1998:166). Chin and Newsted (1999), using Monte Carlo simulation, infer that in PLS it is possible to successfully estimate and detect path loadings of 0.60 and 0.80 at the small sample size of 20 , albeit with reasonably large standard error. However, they also found that increasing the sample size alone does not provide a better approximation to the population value; instead, the number of indicators also has to increase. Their overall results from the Monte Carlo simulation show that the PLS approach can provide information about the appropriateness of indicators at sample sizes as low as 20. Power analysis is useful here in achieving the trade-off between standard error and sample size.

Based on these findings, a sample size of 20 or more samples was considered to be reasonably acceptable for the study.

\section{Data collection}

As at March 2002, there were 51 banks registered in terms of the Banks Act, excluding foreign representative offices. These 51 banks included 30 locally controlled banks, two of which were under curatorship, eight foreign-controlled banks and 15 branches of foreign banks. The number of banks on the list keeps fluctuating as a result of mergers or liquidations. Telephonic communications with the representative offices of foreign banks indicated that most of them had skeleton staff and were not actively involved in banking in South Africa.

Data were collected using a questionnaire, and respondents were requested to respond either by e-mail, post or fax. The questionnaire had three parts. Part A measured uncertainty in the external business environment (of the task environment, which consists of sectors such as customers, suppliers/depositors, competitors and financial markets); Part B measured the degree of support provided by information systems used by the organisation in assessing/predicting uncertainty in various sectors of the external business environment, and Part $\mathrm{C}$ was used to measure the business performance of organisations. The development and validation of the questionnaire is reported in next section.

Altogether, 22 responses were obtained from a population of 51 banks, including the big four: Nedcor, First National Bank, Standard Bank and ABSA. The response rate was poor from the 15 branches of foreign banks. The responses covered more than $90 \%$ of the commercial banking sector in South Africa. All the e-mails were addressed to the chief executive officer of the bank, but some of them responded through their deputies.

\section{Development of measurement instruments}

Three variables were directly measured in the study, namely: 
- $\quad$ Perceived environment uncertainty.

- $\quad$ IS support (IS strategy orientation towards perceived uncertainty).

- Business performance.

The model using PLS terminology and the scales of measurement is shown in Figure 8. The perceived uncertainty (PNV), IS support (ISS) and information systems alignment (ISA) were modelled exogenous latent constructs, while business performance (BP) was a modelled endogenous construct. The measures of PNV, ISS and BP were reflective measures, while ISA had formative measures. The dimensions of alignment caused the alignment.

The questionnaire was divided into three parts, each measuring one of the three listed variables. The following discussion details the development and validation of the measurement scales.

\section{Scale development for measuring perceived environment uncertainty ${ }^{1}$}

The basic structure of Miles and Snow (1978) was used, with some modifications. Miles and Snow (1978: 200) use the six sectors, namely: suppliers of raw materials and components; competitors' action; customers; financial/capital market; government regulatory agencies; and actions of labour unions. These sectors basically represent the manufacturing sector, and the questionnaire was modified for the banking sector during the design. Action of labour was found not to be relevant for the study. Five sectors (namely, depositors and money lenders [as suppliers]; action by competitors; customers; the financial market; and government and regulatory agencies) were considered in the study. A code was given to each sector, and PNV1 represented depositors and moneylenders, PNV 2 represented action by competitors, PNV3 represented customers, PNV4 represented financial market and PNV5 represented Government \& regulatory agencies. Each dimension was operationalised using the questionnaire. Five questions (so-called indicators) were designed for each sector, making a total of 25 questions. The responses were subjected to factor analysis using PLS to determine the reliability of the indicators, and weak indicators were dropped. The scale showed good internal consistency and discriminant validity.

\section{Scale development for measuring business performance}

In line with previous research, business performance was considered as multidimensional, with four dimensions: business growth (BG), profitability or financial profitability (FP), image and customer loyalty (CL) and product service innovativeness (INNOV). Each dimension was operationalised using the questionnaire. Subjective measures should not be used where objective measures are available
(Garg, Joubert \& Pellissier, 2004). The study faced two problems in relying on objective measures. Firstly, there were no objective measures for all the dimensions that were to be measured, for example, customer loyalty and innovativeness. Secondly, the majority of banking businesses in South Africa are conglomerate business units, and in such situations, the data, or parts of the data, are inextricably interwoven with either corporate-wide data or with a class of business. This left no choice but to rely on the responses of management, which was a study limitation. In order to determine the relative importance of each dimension, business performance was considered to be a second order construct, with its four dimensions representing the first order construct, and the first order construct represented by questionnaire items referred to as indicators. From the data collected, the study found that non-financial parameters (namely, customer loyalty and product service innovativeness) were not important dimensions to the respondents as far as business performance is concerned. This suggests that business performance in the banking sector in South Africa is still guided mainly by financial factors. The dimensions of business growth and financial performance have shown a high degree of correlation, which indicates that growth is for profit, or vice versa. This means that the business growth is also aligned with profitability, or that growth for profitability is the concern, and profitability still remains the key measure of business. Accordingly, it was decided to use one construct represented by the six indicators representing business growth and financial performance and coded as BP1 to BP6.

\section{Scale for measuring IS support}

IS strategy orientation towards environmental uncertainty is the support provided by the IS used by the organisation (realised IS strategy) to reduce the gap between perceived environmental uncertainty and realised environmental conditions. This was measured using a parallel questionnaire for measuring environmental uncertainty. There was one parallel question for each of the perceived environmental uncertainty questions to determine the level of support provided by information systems used by the organisation during the previous two years, and at least older than three months. The present information systems observe a very high rate of obsolescence, are faster systems than previous ones and involve high investment. A time lag of one year to allow for performance time lag is therefore unreasonable, and a period of three months is thus assumed to be reasonable for the purposes of this study. The period of two years was used to find the sustained support by the information systems. Systems might change, or might have been updated, but the assessment of support is the key issue. The indicators for perceived uncertainty that could not be validated were not considered in their parallel questionnaire in the final analysis. The use of a parallel questionnaire provided data for measuring alignment in line with the Chan et al. (1997) research instrument.

\footnotetext{
${ }^{1}$ For a detailed analysis related to the selection and validation of instruments, see Garg (2003).
} 


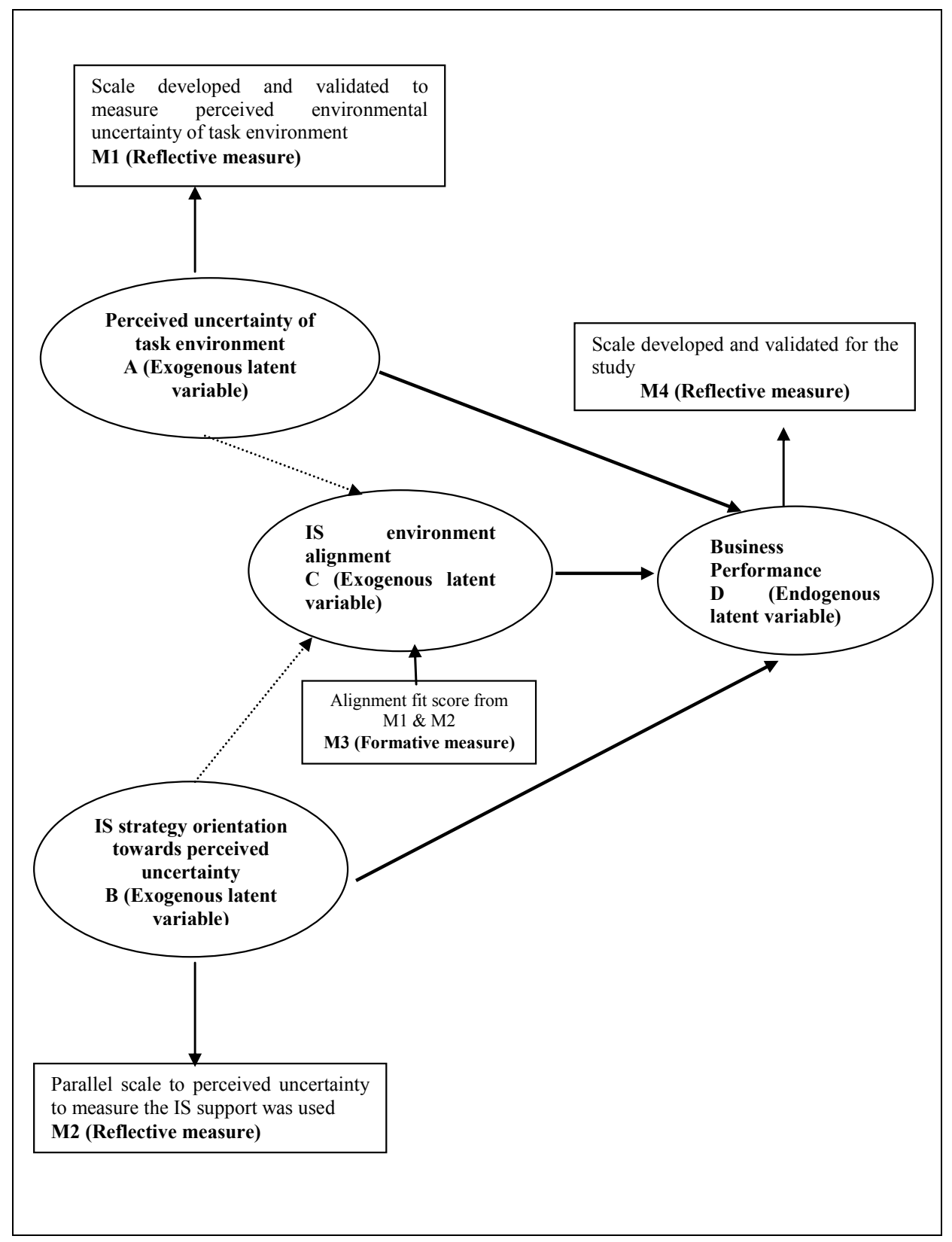

Figure 8: IS environmental alignment model using PLS terminology and showing scales for measuring variables

\section{Limitations of the study}

The limitations of the study included:

- $\quad$ The study used views (subjective data) provided by the senior executives of the bank. However, studies suggest that perceptual data/views from senior executives tend to correlate strongly with objective data (Dawes, 1999).

- The conceptual model mainly aimed to provide evidence of IS support in the management of environmental uncertainty. The study emphasised the importance of IS environmental alignment and considered the aligning techniques used by Chan and Huff (1993b) for aligning business IT strategy. The approach followed is according to Venkatraman's moderation fit only (in other words, studying the synergetic effect of the variables at the same time coinciding with the AND model of organisational design).

- The questionnaire was designed using a six-point rating scale to avoid central tendency. The use of an even number rating scale eliminated the choice of comparing one organisation at par, or exactly similar to another organisation. This possibility is theoretical, and is very rare in practice. However, the use of an even number of choices in the questionnaire is a limitation of the study. 
- The findings cannot be generalised, as it was a case study.

\section{Results and study findings}

As the study was exploratory, the sample size was small, and data were non-parametric, conforming with Partial Least Squares requirements (PLS), and accordingly PLS was used. PLS graph version 03.00 build $1016 @ 1993-2003$ Soft Modeling Inc. (150 variables) was used to run the model. Dr W.W. Chin of the University of Houston licensed the software for this study only.

\section{Descriptive statistics of the responses}

The responses obtained were tabulated. Table 4 provides the descriptive statistics of the responses.

The data revealed that respondents experience the highest degree of uncertainty in the PNV4 sector, followed by PNV2 (in other words, the financial market followed by competitor's action). Conversely, the highest IS support was provided in the customer sector (average score 4.05). The overall score of 3.17 on perceived uncertainty can be interpreted on the higher side on a scale of 6 , while wide variations in the responses were observed.
Descriptive statistics on IS environmental alignment are shown in Table 5. The alignment scores were determined by multiplying (moderation type of alignment) PNV scores with the ISS scores and were coded as ISA in the final model. The maximum possible alignment score was 36 , and the minimum 1. Zero represented 'not applicable' (in other words, no IS support, and there were none in the category of PNV4). There were cases of no support in a single dimension (namely, PNV1, PNV2 and PNV5), but no respondent had a zero alignment score for all dimensions. This indicates that banks use IS support for assessment and predictive purposes in the area of environmental uncertainty. The alignment scores infer that there is considerable alignment variation, as seen from the minimum and maximum scores.

\section{PLS analysis of results and hypothesis}

The 22 responses obtained from banks were used as input to the model. The constructs PNV and ISS were second order constructs and used the same indicators as were used for lower constructs. The results (namely, the path coefficients and $\mathrm{R}^{2}$ results) were transferred to the hypothesised model and shown in Figure 9.

Table 4: Descriptive statistics of the response on environment uncertainty and IS support

\begin{tabular}{|c|c|c|c|c|}
\hline Item & Mean & $\begin{array}{l}\text { Standard } \\
\text { deviation }\end{array}$ & Minimum & Maximum \\
\hline Suppliers (PNV1) Sector1 & 2,87 & 1,21 & 1,00 & 5,67 \\
\hline Competitors (PNV2) Sector2 & 3,28 & 1,00 & 1,00 & 5,00 \\
\hline Customers (PNV3) Sector3 & 3,13 & 0,87 & 2,00 & 5,33 \\
\hline Financial markets (PNV4) Sector4 & 4,14 & 1,06 & 1,67 & 5,67 \\
\hline Government and regulators (PNV5) Sector 5 & 2,49 & 0,85 & 0,67 & 5,00 \\
\hline Overall Av. & 3,17 & & & \\
\hline ISS1* & 3,47 & 1,12 & 1,00 & 5,00 \\
\hline ISS2 & 2,56 & 1,21 & 1,00 & 5,00 \\
\hline ISS3 & 4,05 & 0,97 & 2,00 & 5,33 \\
\hline ISS4 & 3,29 & 1,11 & 1,33 & 5,00 \\
\hline ISS5 & 3,06 & 1,14 & 0,67 & 5,00 \\
\hline Overall Av. & 3,28 & & & \\
\hline
\end{tabular}

* ISS represents IS support for relevant sector

Table5: Descriptive statistics on IS environmental alignment scores (with scores excluding the zero alignment scores)

\begin{tabular}{|c|c|c|c|c|c|}
\hline Dimension/ Sector & $\begin{array}{l}\text { Mean of } \\
\text { alignment scores }\end{array}$ & $\begin{array}{l}\text { Standard deviation } \\
\text { of alignment scores }\end{array}$ & $\begin{array}{c}\text { Minimum } \\
\text { alignment score }\end{array}$ & $\begin{array}{c}\text { Maximum } \\
\text { alignment score }\end{array}$ & $\begin{array}{c}\text { Number of } \\
\text { responses with } \\
\text { no alignment }\end{array}$ \\
\hline Suppliers (PNV1) & 10,18 & 6,55 & 2,67 & 28,33 & 4 \\
\hline Competitors (PNV2) & 7,98 & 3,45 & 3,00 & 13,33 & 3 \\
\hline Customers (PNV3) & 12,60 & 3,61 & 6,00 & 19,67 & 1 \\
\hline Financial markets (PNV4) & 13,24 & 5,08 & 5,00 & 25,00 & None \\
\hline $\begin{array}{l}\text { Government and regulators } \\
\text { (PNV5) }\end{array}$ & 6,94 & 3,39 & 2,00 & 12,00 & 4 \\
\hline
\end{tabular}




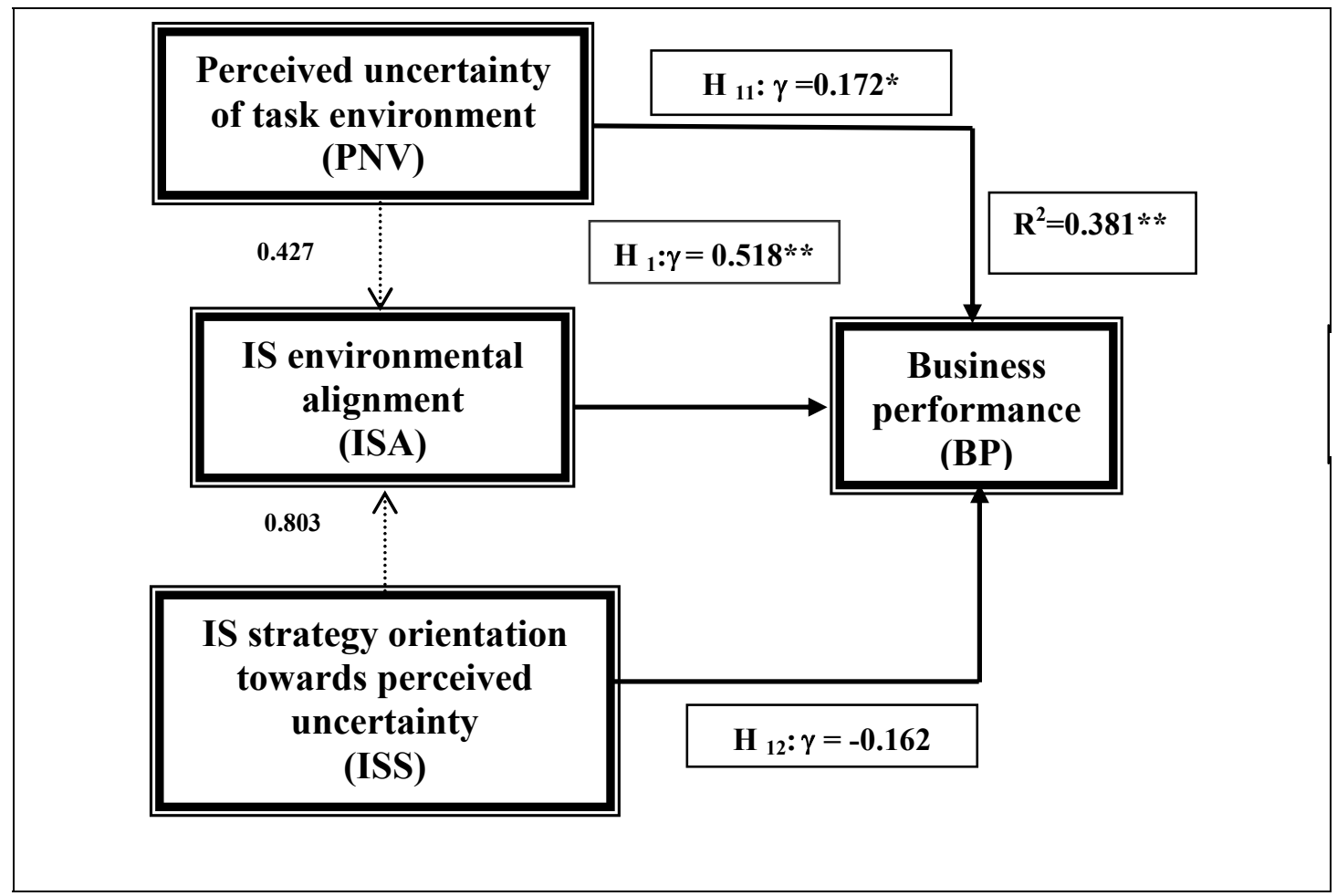

Figure 9: IS environmental alignment model showing the results

Note: Alignment measurement after Chan et al., 1997

$\gamma=$ Path coefficient

* Path statistically significant at $\mathrm{p}=0,025, * *$ statistically significant at $\mathrm{p}=0,05$

The values of the path coefficients ${ }^{2}(\gamma)$ obtained are explained as follows:

$\mathbf{H}_{1}: \gamma=\mathbf{0 . 5 1 8}$ : It is the value of path coefficient between IS environmental alignment and business performance. A value of 0.518 indicates that IS environmental alignment has a positive effect on business performance, as hypothesised in section 4. This result validates the first part of the hypothesis, that 'the IS environmental alignment has a positive effect on business performance $\left(\mathrm{H}_{1}\right)$ '. The $\gamma$ value of $\mathrm{H}_{1}(0.518)$ was found to be higher than the $\gamma$ value of $\mathrm{H}_{11}$ (0.172), and the $\gamma$ value of $\mathrm{H}_{12}(-0.162)$ This validates the second part of the hypothesis, that 'the effect of alignment on business performance is more pronounced than the effect of a directly affecting factor'.

$\mathbf{H}_{11}: \gamma=\mathbf{0 . 1 7 2}$ : A path coefficient value of 0.172 between environmental uncertainty and business performance indicates a positive relationship between the two variables. This result validates the first sub-hypothesis that 'business performance is positively related to the perceived

\footnotetext{
${ }^{2}$ The path coefficients $(\gamma)$ are standardised $\beta$ coefficients, or standardised regression coefficients, that allow researchers to compare directly the relative effect of each independent variable on the dependent variable. (Standardisation is the process whereby raw data are transformed into a new measurement variable with a mean of 0 and a standard deviation of 1 . When data are transformed in this manner, the $b_{0}$ term, or the intercept, assumes a value of 0 . When using standardised data, the regression coefficients are called beta coefficients [Hair et al., 1998: 147]).
}

uncertainty of the task environment, and mathematically $\mathrm{H}_{11}$ $>0$.

$\mathbf{H}_{\mathbf{1 2}}: \gamma=\mathbf{- 0 . 1 6 2}$ : This value suggests that the relationship between IS support and business performance could not be established as envisaged in section 4. This finding has major implications for IT investment (IS capability) in the organisation.

The $\gamma$ value of $\mathrm{H}_{1}$ was found to be higher than the $\gamma$ value of $\mathrm{H}_{11}$, and the values of $\mathrm{H}_{1}$ and $\mathrm{H}_{11}$ were greater than zero. This validates the hypothesis that ' $\mathrm{H}_{1}$ is greater than zero and its value is higher than the values of $\mathrm{H}_{11}$ and $\mathrm{H}_{12}$ '. However, the value of $\mathrm{H}_{12}$ was not found to be positive.

The values of 0.427 and 0.803 are the path coefficients between the constructs that indicate the loading of PNV and ISS constructs on ISA. The higher loading of 0.803 , as compared to 0.427 , suggests that the IS support was stronger than the perceived environmental uncertainty.

$\mathbf{R}^{2}=\mathbf{0 . 3 8 1}$ : A measure of the predictive power of the model is the $\mathrm{R}^{2}$ value for the endogenous construct (namely, business performance). It indicates the amount of variance in the construct that is explained by the model. The results in the model indicate that more than $38 \%$ (39\% when ISS is excluded) of the variance in business performance is explained by the two dependent variables PNV and ISA. The value of 0.381 was found to be statistically significant at a significance level of 0.05 (Hair et al., 1998: 165). 
To assess the statistical significance of path coefficients, which are standardised $\beta$, a re-sampling $\left(\right.$ jackknife $^{3}$ ) analysis was performed using the PLS program, which has inbuilt capacity to run jackknifing. The results of the jackknife, the paths (PNV-BP and ISA-BP), were found to be statistically significant at $\mathrm{p}=0.025$ and $\mathrm{p}=0.05$ respectively (see Table 6 ).

\section{Effectiveness of IT use or IS capability}

As discussed earlier, IS strategic orientation is the support provided by IS that essentially relies on IT. Table 7 shows the effectiveness of IT use (IS capability). It indicates the level of IS support provided by the respondent vis-à-vis requirements based on the perceived uncertainty estimates. Ideally, a higher perceived uncertainty factor would require higher IS support. An average score of 3 in the scale of 6 was considered on the higher side, as two classifications were used (namely, low and high).

Figure 10 is the matrix of alignment. It shows the effectiveness of IT use (IS capability). The horizontal axis plot is the gap between perceived and realised environmental conditions, while the vertical axis plot refers to the IS support provided. As discussed in section 2, the gap is proportional to perceived uncertainty. The effectiveness of alignment is shown by the quadrants. The first and third quadrants are the quadrants of good alignment, while the second and fourth quadrants reflect bad or poor alignment. It is evident that the alignment is bad, or is superimposed on the fourth quadrant, because the IS support provided is much greater than the requirements of the organisation, while in the second quadrant, the IS support provided is lower than the requirements of the organisation, resulting in ineffective use of IT (IS capabilities) or poor alignment.

The plot shows that the alignments for factor PNV3 (customers) and PNV4 (financial markets) are reasonably good. PNV2 (action by competitors) needs more IS support, while IS support could be reduced for PNV1 and PNV5. This means that organisations have made higher IT investments (or have created excessive IS capabilities) in these sectors than they require. The dotted arrows show the direction of movement of a factor for effective alignment. The matrix of alignment provides a conceptual tool to measure and correct the misalignment in organisations.

\footnotetext{
${ }^{3}$ The use of jackknifing, as opposed to the traditional t-test, allows the testing of the significance of parameter estimates from data that are not assumed to be multivariate normal. In jackknifing, a number of subsamples are created by removing one or more cases from the total data set. PLS is used to estimate the parameters of each subsample, and 'pseudovalues' are calculated for the parameters by applying the jackknife formula. The pseudovalues are averaged to form jackknife estimates of the parameters $\left(\mathrm{P}^{*}\right)$. Since the pseudovalues are approximately independent and normally distributed, the jackknife estimates of the parameters $\left(\mathrm{P}^{*}\right)$ and the standard error of the pseudovalues $\left(\mathrm{e}^{*}\right)$ are used to calculate $\left(\mathrm{P}^{*} / \mathrm{e}^{*}\right)$, a student $\mathrm{t}$-value with $\mathrm{n}-1$ degrees of freedom, where $\mathrm{n}$ is the number of sub-samples used in the jackknifing procedure' (Barclay, Higgins \& Thompson., 1995).
}

\section{Negative finding in the study}

When the full model was run using PLS analysis, the indicator BP4 (the after-tax return on asset) showed negative loading. This indicator was dropped from the final analysis, indicating that it was not a valid measure. This finding contradicts the findings of Ansoff and Sullivan (1993) and Rogers and Bamford (2002), who found return on asset to be the most commonly accepted measure of performance in the banking industry. Contrary to their findings, the current study found that profitability is the key concern, although return on asset is related to profitability. Further analysis could be done to establish the cause of this negative finding. Highly leveraged firms, in terms of capital employed, could partly explain the findings, meaning that if equity investment is very small compared to debt, owners will be less interested in return on asset than in profitability. An after-tax return equivalent to about $0.4 \%$ of total assets for 2002 (South African Reserve Bank, 2002) and similar trends (around 1\%) in the past years in the banking sector in South Africa support this negative finding.

\section{Other findings}

The following were the study findings:

- The results suggest that it is not the IS support or investment in IT that impacts on business performance, but rather the effective use of IS to support the information needs of organisations, no matter how substantial the IT investment. The path joining IS support and business performance could not be validated. The relationship between IS environmental alignment and business performance was also reasonably high and statistically significant. IS alignment was found to be a better predictor of business performance. The investment in IT is meaningless unless the IS support is aligned with the management of environmental uncertainty, which impacts on performance.

- IS environmental alignment was conceptualised as the support provided by IS strategy to minimise the gap between perceived environmental uncertainty and realised environmental conditions. The responses to the part of the questionnaire that addressed information processing and predicting capabilities of IS indicates the extent of support provided by IS in the assessment of uncertainty in the external business environment in the banking sector in South Africa. The results suggest that organisations are using IS support to enhance the information processing and prediction capabilities of their information systems for the management of environment uncertainty. IS environmental alignment is a valid concept.

- The study found a positive but weak relationship between perceived environmental uncertainty and business performance. This is attributed to the fact that the banks in the study sample were using IS support to assess the business environment, and this capability has helped them to manage environmental uncertainty, which has impacted business performance in a positive 
way. This finding is in line with Galbraith (1973), namely, that organisations that perceive the objective environment correctly will be more effective. The respondents perceived the highest uncertainty in financial markets, followed by competitors' action, customers, suppliers, and government and regulatory authorities. High uncertainty in financial markets, associated with less uncertainty about the actions of government and other regulatory authorities, compared to other factors, could make South Africa a good place for long-term investment.

- In the study, measurement instruments to measure business performance and environmental uncertainty in the South African banking sector were developed and validated.
- The results also suggest that the non-financial dimensions (namely, customer loyalty and product service innovation) are not valid dimensions for measuring business performance, while the other two dimensions (namely, business growth and profitability) show a high degree of correlation. This indicates that business growth is aligned with profitability, and that growth for profitability is the concern, and profitability still remains the key measure of business performance in the banking sector in South Africa. Parameters such as customer loyalty and innovativeness are not regarded as important for business performance, although these could be pressing issues for banks.

Table 6: Jackknife estimates and statistical significance for paths

\begin{tabular}{l|c|c|c|c|c|c}
\hline \multicolumn{1}{c|}{ Path } & $\begin{array}{c}\text { Original } \\
\text { estimates }\end{array}$ & $\begin{array}{c}\text { Mean of sub- } \\
\text { sample }\end{array}$ & $\begin{array}{c}\text { Jackknife } \\
\text { estimates } \\
(\mathbf{P} *)\end{array}$ & $\begin{array}{c}\text { Standard error } \\
\left(\mathbf{e}^{*}\right)\end{array}$ & $\begin{array}{c}\mathbf{t} \text { statistics } \\
\left(\mathbf{P} * / \mathbf{e}^{*}\right)\end{array}$ & $\begin{array}{c}\text { Statistical } \\
\text { significance at } \mathbf{p}=\end{array}$ \\
\hline PNV-BP & 0,172 & 0,1562 & 0,4882 & 0,2267 & 2,1538 & $\mathrm{p}=0,025$ \\
\hline ISA-BP & 0,518 & 0,5165 & 0,5485 & 0,2956 & 1,8557 & $\mathrm{p}=0,05$ \\
\hline ISS-BP & $(-) 0,162$ & $(-) 0,1670$ & $(-) 0,0610$ & 0,2075 & 0,2942 & Not significant \\
\hline
\end{tabular}

Table7: Effectiveness of IT use (IS capability) and its implication on IS environmental alignment (results)

\begin{tabular}{|c|c|c|c|c|}
\hline $\begin{array}{l}\text { Perceived uncertainty of an } \\
\text { environmental factor (as measured by } \\
\text { unpredictability of change) (Average } \\
\text { score) }\end{array}$ & $\begin{array}{c}\text { Gap between } \\
\text { perceived } \\
\text { uncertainty and } \\
\text { realised } \\
\text { environmental } \\
\text { conditions } \approx \\
\text { environmental } \\
\text { factor uncertainty }\end{array}$ & $\begin{array}{l}\text { IS support provided in } \\
\text { reducing the gap } \approx \text { IS } \\
\text { support in } \\
\text { perceiving/assessing } \\
\text { the factor uncertainty } \\
\text { (Average scores) }\end{array}$ & $\begin{array}{l}\text { Effectiveness of IT } \\
\text { use or IS capability }\end{array}$ & $\begin{array}{c}\text { IS environmental } \\
\text { alignment }\end{array}$ \\
\hline PNV1 & 2,87 (Low) & 3,47 (High) & Waste & Bad/superimposed \\
\hline PNV2 & 3,28 (High) & 2,56 (Low) & Ineffective & Poor \\
\hline PNV3 & 3,13 (High) & 4,05 (High) & Effective & Good \\
\hline PNV4 & 4,14 (High) & 3,29 (High) & Effective & Good \\
\hline PNV5 & 2,49 (Low) & 3,06 (High) & Waste & $\mathrm{Bad}$ \\
\hline
\end{tabular}

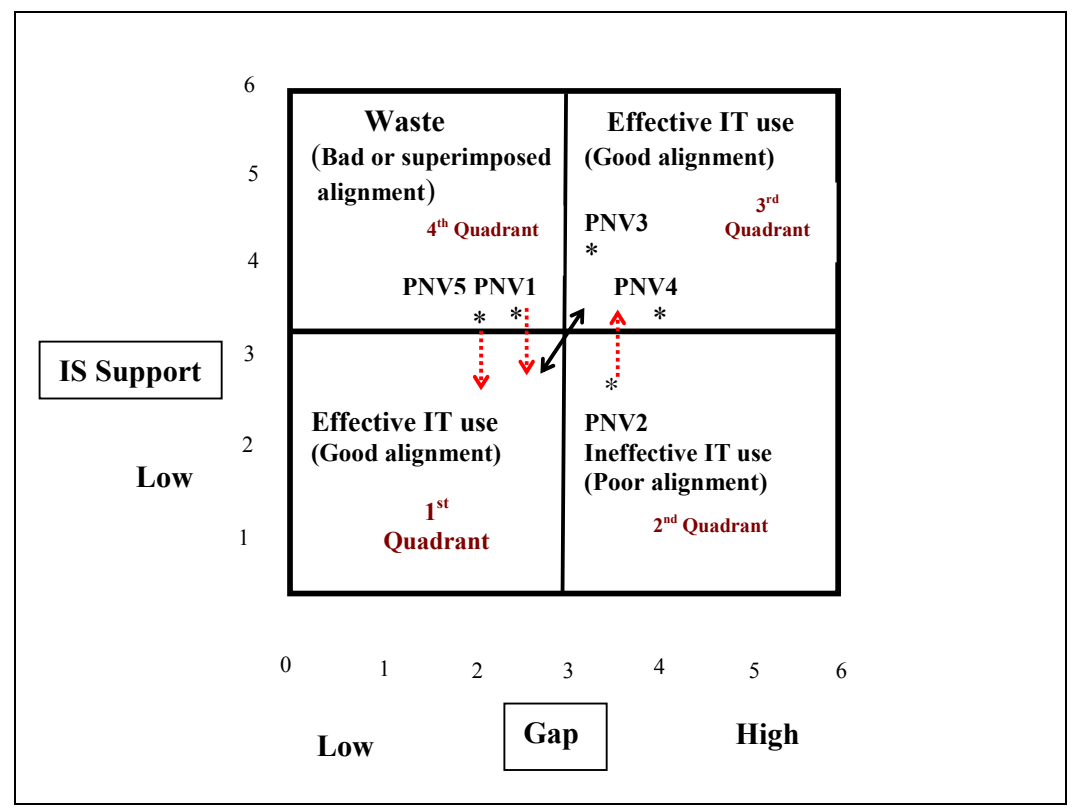

Figure 10: Matrix of alignment showing effectiveness of IT use (IS capability) 


\section{Discussion and conclusions}

The external business environment is important to business, as it impacts business performance. The study of the impact of environmental uncertainty on business performance is crucial for the successful management of the environment. Using empirical data, this study was able to establish a weak relationship between uncertainty in the task environment and business performance, which validates the importance of environmental uncertainty in business. Previous studies have not been able to establish the direct relationship between these two variables.

This study concludes that the capabilities of IS facilities that essentially rely on IT can, as a result of IT investment, be extended beyond the role of gaining competitive advantage in the marketplace. These facilities can be used to enhance the information processing and predicting capabilities of the organisation. The study has validated the role of IS in supporting information processing and predictability capabilities for assessing environmental uncertainty in the banking sector in South Africa. Accordingly, the study recommends that organisations use IS facilities to enhance their information processing and predicting capabilities, not only for the purposes of managing the external environment, but for the sake of other functionalities of the organisation (for example, assessing risk management and building sophisticated tools for business data analysis and prediction). This role of IS in organisations is an extension of the existing role of the strategic management of IS.
Based on the analysis of empirical data and the associated findings, this study further suggests that IT investment (in hardware, software and the communication network) alone cannot impact performance, but that the alignment of IS support (derived from such investment) with the needs of organisations affects business performance. The concept of IS environmental alignment in this study is an example of such application and can be extended to other areas of organisations, as it is empirically validated by this study. Organisations need to expand the scope of application of their investment to the needs of the organisation, but aligning the investment with the needs of the organisation is the key to getting returns from the investment. Finally, considering environmental uncertainty as an independent variable and analysing empirical data, this study has contributed towards an understanding of the relationship between environmental uncertainty, IS strategy and business performance. Figure 11 indicates the contribution to the body of theory. Figure 2 shows the tower of IS alignment for the effective use of IS in organisations.

On the basis of the findings of the study, it is possible to develop an 'environmental uncertainty dashboard' (EUD) to measure and reflect external business environmental uncertainty. Further research could explore various types of alignment. The other five fits of Venkatraman (1989) could also be explored.

\section{Acknowledgement:}

We express our sincere thanks to both anonymous referees for their constructive comments. The views expressed in the paper are our own.

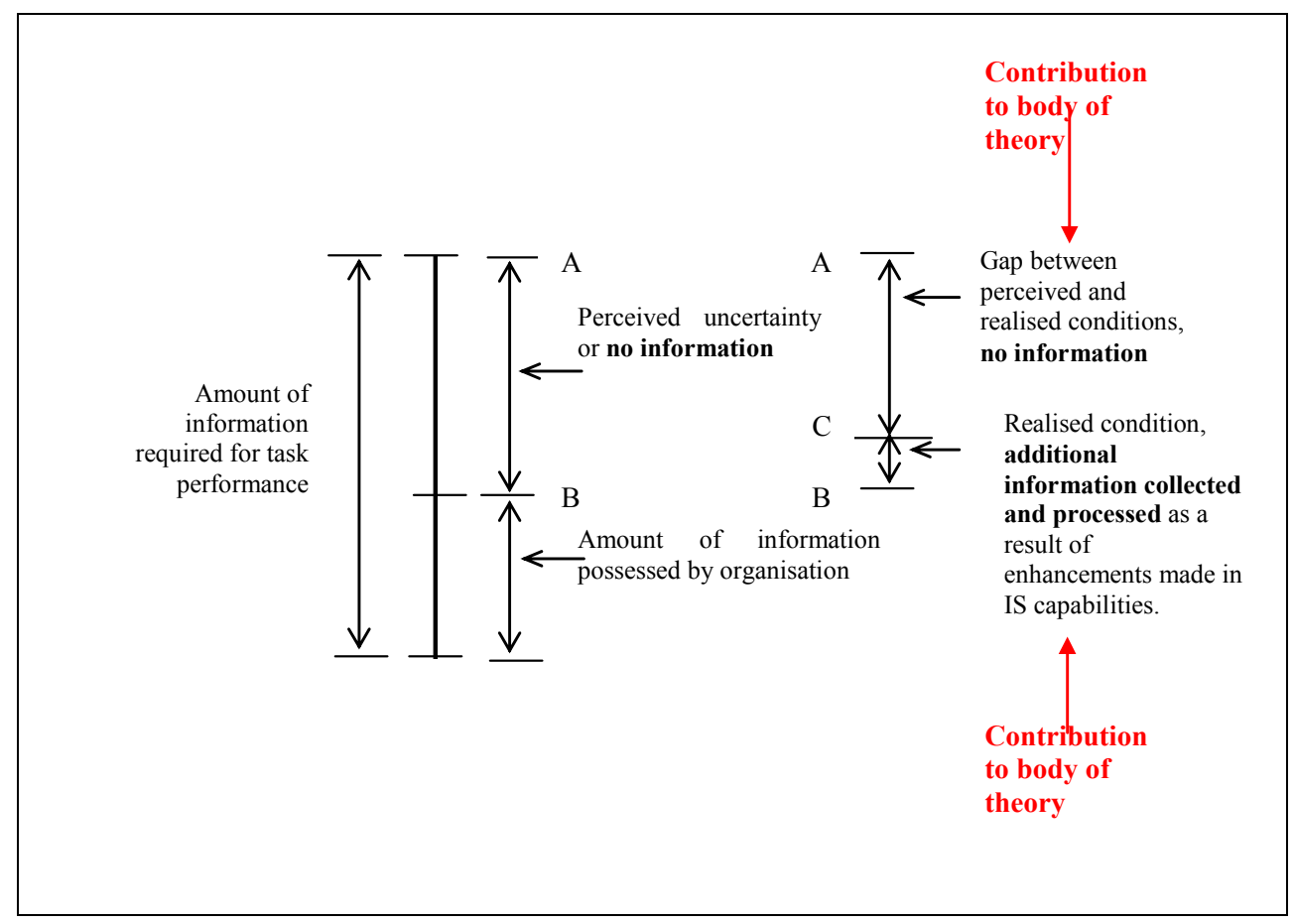

Source: Adapted from Galbraith (1977)

Figure 11: Gap between perceived and realised conditions showing contribution to body of theory 


\section{References}

Anderson, T.J. 2000. 'Strategic planning, autonomous actions and corporate performance', Long Rang Planning, 33:184-200.

Anderson, T.J. 2001. 'Information technology, strategic decision-making approaches and organisational performance in different industrial settings', Journal of Strategic Information Systems, 10: 101-119.

Ansoff, H.I. \& Sullivan, P.A. 1993. 'Optimising profitability in turbulent environments: A formula for strategic success', Long Range Planning, 26(5): 11-23.

Avison, D.E., Cuthbertson, C.H. \& Powell, P. 1999. 'The paradox of information systems: Strategic value and low status', Journal of Strategic Information Systems, 8: 419445.

Badri, M.A., Davis, D. \& Davis, D. 2000. 'Operations strategy, environmental uncertainty and performance: A path analytic model of industries in developing countries', The International Journal of Management Science, 28:155173.

Barclays, D., Higgins, C. \& Thompson, R. 1995. 'Partial least squares (PLS) approach to causal modeling: personal computer adoption and use as an illustration' (with commentaries), Technology Studies, 2(2): 285-309.

Bergeron, F., Raymond, L. \& Rivard, S. 1999. 'The concept of fit in information systems research'. [online] URL:www.fsa.ulaval.ca/rd. Accessed 19 November 2001.

Boyd, B.K. \& Fulk, J. 1996. 'Executive Scanning and Perceived Uncertainty: A Multidimensional Model', Journal of Management, 22(1): 1-21.

Broadbent, M. 1996. 'Linking management and information systems through case analysis of International Business Operations'. Proceedings of the International Conference on the Place of Information Technology in Management and Business Education, Melbourne, Australia. London: Chapman \& Hall, London.

Brown, C.V. \& Magill, S.L. 1994. 'Alignment of the IS function with the enterprise: towards a model of antecedents', MIS Quarterly, 14(8). [online] URL:http://web2.infotrac.London.gal/purl. Accessed 7 May 2001.

Burke, W.W. \& Litwin, G.H. 1992. 'A causal model of organisational performance and change', Journal of Management, 18(2): 523-545.

Chan, Y. E. 1997. 'Aligning business and information systems strategy and structure: Eight case studies'. Working Paper No. 97-07, Queen's School of Business, Canada.

Chan, Y.E., Huff, S.L., Barclay, D.W. \& Copeland, D.G. 1997. 'Business strategic orientation, information systems strategic orientation, and strategic alignment', Information Systems Research, 8(2): 125-150.

Chan, Y.E, Huff, S.L., Barclay, D.W. \& Copeland, D.G. 1998. 'Assessing realized information systems strategy', Journal of Strategic Information Systems, 6: 273-298.

Chan, Y.E. \& Huff, S.L. 1993a. 'Strategic information systems alignment', Business Quarterly, 58(1): P51 (5). Accessed from Expanded Academic ASAP Int'l Ed., Unisa Library, 5 July 2001.

Chan, Y.E. \& Huff, S.L. 1993b. 'Investigating information systems strategic fit: A novel approach'. Working Paper No. 93-11, Queen's School of Business, Canada.

Chin, W.W. \& Newsted, P.R. 1999. 'Structural equation modeling analysis with small samples using partial least squares'. In Hoyle, R.H. (Ed.). Statistical strategies for small sample research. California: Sage.

Chin, W.W. 1998. 'The partial least square approach to structural equation modeling'. In Marcoulides, G.A. (Ed.). Modern methods for business research modeling. New Jersey: Lawrence Erlbaum.

Cragg, P.C., King, M. \& Hussain, H. 2002. 'IT alignment and firm performance in small manufacturing firms', Journal of Strategic Information Systems, 11: 109-132.

Croteau, A.M. \& Bergeron, F. 2001. 'An information technology trilogy: Business strategy, technological deployment and organisational performance', Journal of Strategic Information Systems, 10: 77-99.

Davies, B.P. 2002. Information systems: An introduction to informatics in organisations. Hampshire: Palgrave.

Dawes, J. 1999. 'The relationship between subjective and objective company performance measures in market orientation research: further empirical evidence'. [online]URL:http://marketing-bullein.massey.ac.nz. Accessed 19 April 2002.

Dess, G.G. \& Keats, B.W. 1987. 'Environmental assessment and organisational performance: an exploratory field study', Academy of Management Proceedings, 21-25.

Duncan, R. B. 1972. 'Characteristics of organisational environments and perceived environment uncertainty', Administrative Science Quarterly, 17: 313-327.

Earl, M.J. 1989. Management strategies for information technology. New York: Prentice Hall.

Ebrahimini, B.P. 2000. 'Perceived strategic uncertainty and environment scanning behaviour of Hong Kong Chinese executives', Journal of Business Research, 49: 67-77.

Ensign, P.C. 2001. 'The concept of fit in organisation research', International Journal of Organisation, Theory and Behaviour, 4 (3\&4): 287-306. 
Frishammar, J. 2002. 'Characteristics in information processing approaches', International Journal of Information Management, 22: 143-156.

Galbraith, J.R. 1973. Designing complex organisations. Reading, MA: Addison-Wesely.

Galbraith, J.R. 1977. Organisation design. Reading, MA: Addison-Wesley.

Garg, A.K. 2003. 'Information systems environmental alignment and business performance: A case study for banking sector in South Africa'. Unpublished DBL thesis University of South Africa, Pretoria. Available at UNISA library.

Garg, A.K., Joubert, R.J.O. \& Pellissier, R. 2002. 'Review of strategic alignment: Its meaning, measurement and impact on business performance', Southern African Journal of Business Review, 6(1): 38-44.

Garg, A.K., Joubert, R.J.O. \& Pellissier, R. 2003. 'IS environmental alignment and business performance: A conceptual approach', South African Journal of Industrial Engineering, 14(1): 51-66.

Garg, A.K., Joubert, R.J.O. \& Pellissier, R. 2004. 'Measuring business performance: A case study', Southern African Journal of Business Review, 8(1): 7-21.

Grant, R. M. 1991. Contemporary strategy analysis: Concepts, techniques, applications. Cambridge, MA: Blackwell Publishers.

Groenewald, M. 1999. 'Towards an electronic commerce policy for South Africa', [online] URL:www.legalnet.co.za/cyberlaw/cybertext/.

Hair, J.F., Anderson, R.E., Tatham, R.L. \& Black, W.C. 1998. Multivariate analysis. $5^{\text {th }}$ edition. New Jersey: Prentice Hall.

Henderson, J. \& Venkatraman, N. 1990. 'Strategic alignment: a model for organisational transformation via information technology'. Working Paper No. 217, Sloan School of Management, MIT.

Henderson, J. \& Venkatraman, N. 1993. 'Strategic alignment: Leveraging information technology for transforming organisations', IBM Systems Journal, 32(1): 4-16.

ITweb News. 2002. [online] URL: http://allafrica.com/stories/200211150559 html.

Kanungo, S., Sadavarti, S. \& Sriniwas, Y. 2001. 'Relating IT strategy and organisational culture: An empirical study of public sector units in India', Journal of Strategic Information Systems, 10: 29-57.

Kearns, G.S. \& Lederer, A.L. 2000. 'The effect of strategic alignment on the use of IS-based resources for competitive advantage', Journal of Strategic Information Systems, 9: 265-293.

Langford, B.E. \& Hunsicker, F.R. 1996. 'An integrated view of the relationship between the organisation and its environment'. [online] URL: www.westga.edu/ bquest/1996/model html Accessed 10 August 2001.

Lederer, A.L. \& Mendelow, A.L. 1990. 'The impact of the environment on the management of information systems', Information Systems Research, 1(2):205-223.

Luftman, J. \& Oldach, S.H. 1996. 'Introduction'. In Luftman, J. Competing in the information age: Strategic alignment in practice. New York: Oxford University Press.

Luftman, J. 2000. 'Aligning business-IT alignment maturity', Communications of the Association for Information Systems, 4:1-50.

Luftman, J., Papp, R. \& Brier, T. 1999. 'Enablers and inhibitors of business-IT alignment', Communications of the Association for Information Systems, 1: 1-33. [online] URL: http://cais.isworld.org/articles/1-11/article.htm

Lumpkin, G.T. \& Dess, G.G. 2001. 'Linking two dimensions of entrepreneurial orientation to firm performance: The moderating role of environment and industry life cycle', Journal of Business Venturing, 16(5): 429-451.

Miles, R.E. \& Snow, C.C. 1978. Organisational strategy, structure, and process. New York: Mc Graw-Hill.

Milliken, F.J. 1987. 'Three types of perceived uncertainty about the environment: state, effect and response uncertainty', Academy of Management Review, 12(1): 133143.

Pagell, M. \& Krause, D.R. 1999. 'A multiple-method study of environmental uncertainty and manufacturing flexibility', Journal of Operations Management, 17(3): 307-325.

Pankratz, H. 1991. 'Strategic alignment: managing for synergy’, Business Quarterly, 55(3):66-71.

Papke-Shields, K.E., \& Malhotra, M.K. 2001. 'Assessing the impact of the manufacturing executive's role on business performance through strategic alignment', Journal of Operations Management, 19: 5-22.

Papp, R. 1995. 'Business and IT strategic alignment: New perspectives and assessment'. [online] URL:http://hsb.baylor.edu/ramsower/acis/papers/papp.htm. Accessed 4 June 2001.

Peters, S.C.A., Heng, M.S.H. \& Vet, R. 2002. 'Formation of the information systems strategy in global financial services company', Information and Organisation, 12: 19-38.

Pfeffer, J. \& Salancik, G.R. 1978. The external control of organisations. New York: Harper and Row. 
Porter, M.E. 1980. Competitive strategy: Techniques for analysing industries and competitors. New York: Free Press.

Reich, B.H. \& Benbasat, I. 1996. 'Measuring the linkage between business and information technology objectives', MIS Quarterly, 20(1): 55(27). Accessed from Expanded Academic ASAP Int'l Ed. Unisa Library, 5 July 2001.

Rogers, P.R. \& Bamford, C.E. 2002. 'Information planning process and strategic orientation: The importance of fit in high-performing organizations', Journal of Business Research, 55: 205-215.

Salmela, H., Lederer, A.L. \& Reponen, T. 2000. 'Information systems planning in a turbulent environment', European Journal of Information Systems, 9: 3-15.

Sambamurthy, V., Zmud, R.W. \& Byrd, T. A. 1994. 'The comprehensiveness of IT planning process: A contingency approach', Journal of Information Technology Management, 5(1):1-10.

Sawyerr, O.O. 1993. 'Environmental uncertainty and environmental scanning activities of Nigerian manufacturing executives: A comparative analysis', Strategic Management Journal, 14: 287-299.

Scott, W. R.1992. Organisations: Rational, natural and open systems. Englewood Cliffs, NJ: Prentice-Hall.

Smircich, L. \& Stubbart, C. 1985. 'Strategic management in an enacted world', Academy of Management Review, 10(4): 724-736.

South Africa Business Guidebook 2001/2002, reported on @ Africa Business Direct website.

South African Reserve Bank. Bank Supervision Department. 2002, 2001, 2000. Annual Reports, for the years 2002, 2001, 2000. [online]URL: http://www.reservebank.co.za/.

Sun, H. \& Hong, C. 2002. 'The alignment between manufacturing and business strategies: its influence on business performance', Technovation, 22(11): 699-705.

Tan, F.B. 1999. 'Exploring business-IT alignment using the repertory grid'. Proceedings of $10^{\text {th }}$ Australasian Conference on Information System. [online] URL: www.vuw.ac.za nz/acis99/PaperTan-187.pdf.

Venkatraman, N. 1989. 'The concept of fit in strategy research', Academy of Management Review, 14(3): 423444.

Ward, J. \& Peppard, J. 2002. Strategic planning for information systems. $3^{\text {rd }}$ edition. New York: John Wiley \& Sons, Ltd.

Weick, K.E.1979. The social psychology of organising. New York: McGraw-Hill.
Woolfe, R. 1993. 'The path to strategic alignment', Information Strategy, 9(2): : 13-23.

Zhang, M.J. \& Lado, A.A. 2001. 'Information systems and competitive advantage: A competency-based view', Technovation 21:147-156. [online] URL: www.elsevier.com/locate/technovation. Accessed 3 May 2002. 